\title{
Hydrogeochemistry characteristics of groundwater and health risk assessment in Yalvaç-Gelendost basin (Turkey)
}

\author{
Ayşen Davraz ${ }^{1}$ D $\cdot$ Burcu Batur $^{1}$ (D)
}

Received: 22 February 2021 / Accepted: 26 March 2021 / Published online: 5 April 2021

(c) The Author(s) 2021

\begin{abstract}
In this study, hydrogeochemical processes controlling groundwater chemistry and groundwater quality were investigated. Drinking water is supplied from groundwater (mostly spring and well water) in the study area. The various parameters such as physicochemical parameters, major ions, trace elements and nitrogen derivatives of groundwater samples of were analyzed. These analysis results are compared with drinking water standards for suitability and it does not exceed the permissible limit values, except for the As and F contents of some samples. The results of major ion chemistry of groundwater in the YalvaçGelendost basin suggest that the silicate weathering and ion exchange are the main controlling hydrogeochemical processes in the variation of groundwater quality. The water types are $\mathrm{Ca}-\mathrm{Mg}-\mathrm{HCO}_{3}, \mathrm{Mg}-\mathrm{Ca}-\mathrm{HCO}_{3}$ and $\mathrm{Ca}-\mathrm{HCO}_{3}$ in the basin. Non-carcinogenic health risk assessment associated with arsenic, nitrate and fluoride was assessed by oral (ingestion) and dermal pathways for adult and child. For child, hazard coefficient and hazard index values are less than 1, and a negative effect on usage as drinking water and dermal (skin contact) absorption not expected. But, potential non-carcinogenic effect with oral intake is likely to occur for some water samples for adults. In addition, carcinogenic risk of As element was evaluated for adults and child related to oral and dermal effect. The carcinogenic risk of As through oral intake may pose health risks for children. For adults, it has been determined that water ingestion with dermal exposure may cause cancer. Arsenic is the main toxic element for human health in the study area. The content of As decreases in seasonal water samples. In this case, the negative effect of arsenic intake with ingestion and dermal pathways on health decreases.
\end{abstract}

Keywords Health risk $\cdot$ Hydrogeochemical processes $\cdot$ Groundwater quality $\cdot$ Spring $\cdot$ Turkey

\section{Introduction}

While the need for surface and groundwater resources has increased in the last century with population growth and industrialization, increasing human pressure has also negatively affected existing water resources in terms of quality and quantity. There are important problems in meeting the drinking, using and irrigation water needs of many countries in the world. Nowadays, surface waters are more exposed to adverse effects and become unusable due to their easy accessibility. This situation has caused the groundwater to take a large place in meeting the water needs for different purposes. Today, groundwater is considered a vital resource

Ayşen Davraz

aysendavraz@sdu.edu.tr

1 Department of Geological Engineering, Faculty of Engineering, Süleyman Demirel University, Isparta, Turkey for drinking, domestic, agricultural and industrial purposes worldwide (Shakerkhatibi et al. 2019). However, in many studies it is stated that groundwater is also contaminated with different pollutants and is unusable (Kumar Singh et al. 2012; Narsimha and Sudarshan 2017; Jalali et al. 2019; Sarvestani and Aghasi 2019; Asare-Donkor and Adimado 2020; Malakootian et al. 2020). The most important factor polluting groundwater is anthropogenic pollution. This factor is entirely due to human activities (industrial and agricultural activities, urbanization, wastewater, waste storage, etc.). However, the quality of groundwater can be negatively affected depending on geological factors. Knowing the hydrogeochemical characteristics of groundwater is vital for the determination of usage areas, groundwater planning and management studies.

The chemistry of groundwater changes with degree of chemical weathering of the various rock types, aquifer composition interacting along the flow path, general geology and interaction time. The hydrogeochemical processes 
help to get an insight into the contributions of rock-water interaction and anthropogenic influences on groundwater quality (Kumar et al. 2009). Hydrochemical evaluation of groundwater systems is usually based on the availability of a large amount of information concerning groundwater chemistry (Aghazadeh and Mogaddam 2011). In most recent studies, hydrogeochemical processes controlling the chemistry of groundwater have been studied (Subramani et al. 2010; Pazand et al. 2012; Tay 2012; Zaidi et al. 2015, 2019). These processes affect aquatic chemistry differently because the aquifer environment, rocks and geological structure are different. Therefore, it is important to define groundwater chemistry and hydrogeochemical processes in each region.

With the widespread use of groundwater as drinking water, health problems arise due to the chemistry of groundwater and its pollutants such as trace elements and nitrogen derivatives. There are many studies on drinking water-related health risk assessments. The majority of these studies are related to heavy metal, fluoride, nitrate and microbiological pollution (Shankar et al. 2014; Liu et al. 2015; Davraz et al. 2016; Varol and Davraz 2016; Jalali et al. 2019; Sarvestani and Aghasi 2019; Malakootian et al. 2020; Shukla and Saxena 2020).

In the Yalvaç-Gelendost basin chosen as a research area, the need for drinking and domestic water is fully met by groundwater. There is little awareness of water quality and health risks among people associated with water consumption in this region. There are no studies investigating groundwater quality and related human health risks in the study area. The main objectives are (1) to determine hydrogeological features of basin, (2) to determine hydrogeochemical characteristics of groundwater used as drinking water, (3) to identify of hydrogeochemical processes controlling water chemistry, (4) to evaluate water quality for drinking water and (5) to assess human health risk.

\section{Study area}

The Yalvaç-Gelendost basin covers a fairly large area in the catchment area of the Eğirdir Lake which is second largest freshwater lake of Turkey (Fig. 1). Yalvaç and Gelendost districts are the most important settlements in the basin with an area of $1165 \mathrm{~km}^{2}$. There are many villages belonging to these districts. Agriculture is the most important source of income in the region. The annual average precipitation was determined as $490 \mathrm{~mm}$ with isohyetal method for a period of 47 years (1970-2017). The hottest months are July and August, and the average highest temperature value measured in Yalvaç district is $22.9^{\circ} \mathrm{C}$. The most important river of the study area is Yalvaç stream. All of the streams in the basin are discharged to the Eğirdir Lake. Drainage area and average annual flow of Yalvaç stream are $1159.58 \mathrm{~km}^{2}$ and
$63.40 \times 10^{6} \mathrm{~m}^{3} /$ year, respectively (Soyaslan 2004). Springs are important drinking water sources in the basin.

\section{Geology and hydrogeology}

The Yalvaç-Gelendost basin is located in the northern part of the Western Taurus section in the Taurus belt. In the study area, there are units belonging to Anamas-Akseki autochthonous and Beyşehir-Hoyran-Hadim nappes and Neootochthonous cover rocks. Anamas-Akseki autochthonous is represented by the formations of Sultandağ and Çay units in the region. Formations belonging to Sultandağ unit in the study area are Gökoluk, Çaltepe, Seydişehir, Ergenli, Kurucaova, Hacialabaz, Gölgeli formations and Hüdai Quartzite. The oldest unit of Anamas-Akseki autochthonous is Precambrian Gökoluk formation. There is only Tertiary aged Değirmendere formation belonging to Çal unit in the study area. Beyşehir-Hoyran-Hadim nappes in the basin are represented by Marmaris Peridotite of the Marmaris Ophiolite nappe, Dutdere and Bakırdağ formations of the Domuzdağ nappe (Umut 2009). Neo-otochthonous cover rocks are Bağkonak, Yarıkkaya, Göksöğüt and Kepeztepe formations and slope debris and alluvium (Fig. 1). The lithological and hydrogeological properties of stratigraphic units within the Yalvaç-Gelendost basin are summarized in Table 1. The surroundings of the Yalvaç Neogene basin are mostly a triangular area bounded by normal faults, but exhibits a triangular structure. The thrust and reverse faults in the study area and its surroundings developed in the preNeogene units (Yağmurlu 1991).

In the study area, alluvium has a porous aquifer feature with significant groundwater potential and is the most important aquifer. There are many wells drilled in the alluvium unit in the basin. Groundwater is taken from the sand and gravel levels in the wells drilled in the alluvium. Groundwater is taken from the limestones on the alluvium floor near Gelendost Plain and Tokmacık, Çaltı and Akçaşar villages in the study area. The groundwater flow direction of the alluvium aquifer is toward the Eğirdir lake (Soyaslan 2004; Davraz et al. 2009). The limestones are units with a karstic aquifer feature with significant groundwater potential. The dominant lineament direction in the limestones on the shore of Lake Eğirdir is toward the lake. In addition, there are springs discharged from limestones in the lake shore (Soyaslan 2004; Sener and Soyaslan, 2006). This shows that the dominant groundwater flow direction in the limestones is toward Eğirdir Lake.

Drinking water in the study area is mostly supplied from springs. The most important water resource in the region is the Suçikan spring, the only drinking water source of Yalvaç district, which is the largest settlement. The spring is discharged from the fault zone along the contact of Çaltepe formation and Seydişehir formation (Fig. 2). The yield of 


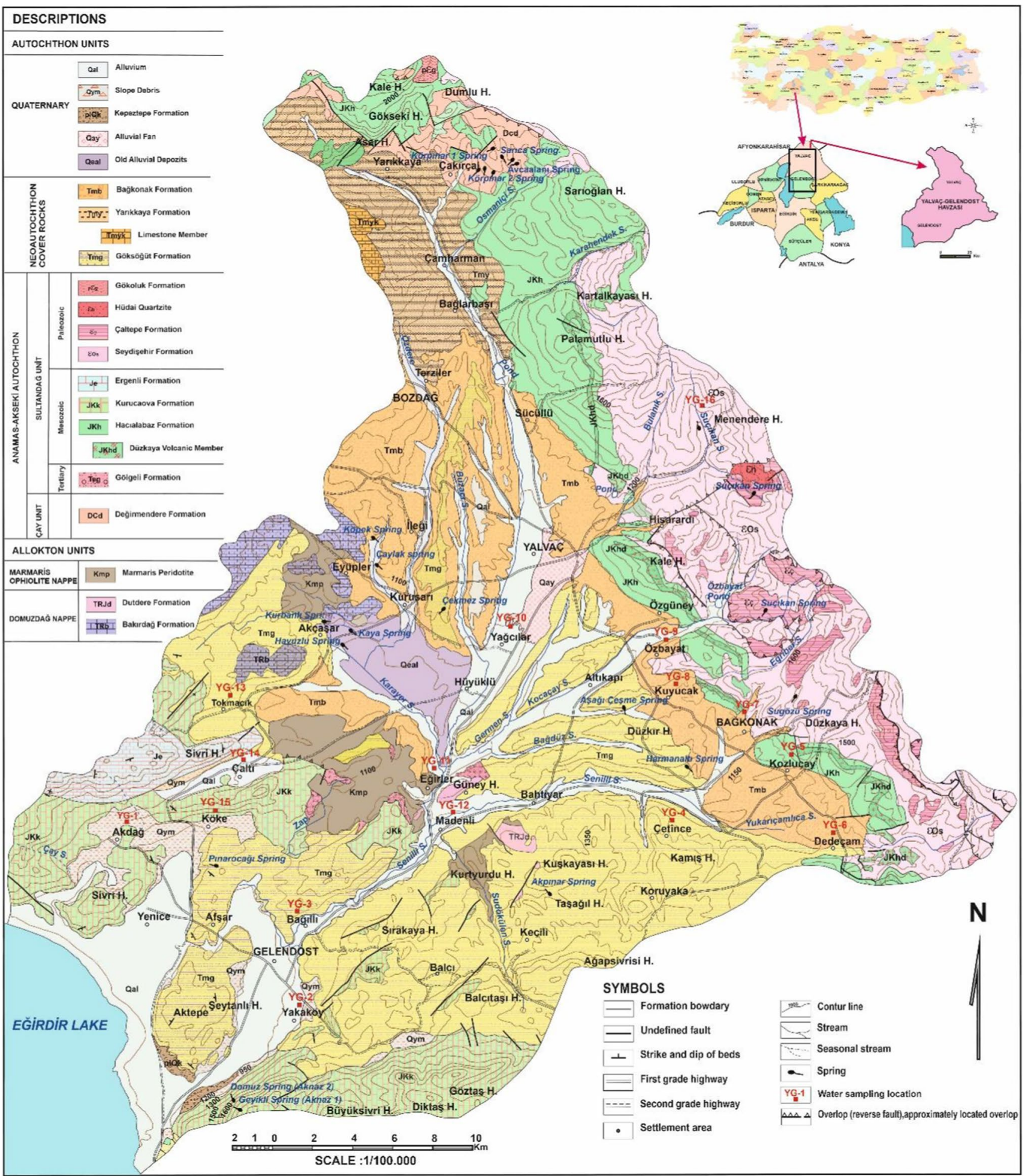

Fig. 1 Geological and location map of the Yalvaç-Gelendost basin

the spring is approximately 70-85 l/s (Soyaslan 2004). The water need of the ancient city of Pisidia Antiokheia, which was established in the north of Yalvaç district, was met from the Suçıkan spring. The ruins of the approximately $10 \mathrm{~km}$ long waterway are observed in the ancient city of Pisidia Antiokheia.

The second important water source in the region is the Bağkonak Sugözü spring. The spring located in the 
Table 1 The lithological and hydrogeological properties of stratigraphic units

\begin{tabular}{|c|c|c|c|c|c|c|}
\hline Rocks & Group & Ages & Formation & Symbol & Lithology & $\begin{array}{l}\text { Hydrogeological } \\
\text { properties }\end{array}$ \\
\hline \multirow[t]{9}{*}{$\begin{array}{l}\text { Neo-otochthonous } \\
\text { Cover rocks }\end{array}$} & & Quaternary & Alluvium & Qal & $\begin{array}{l}\text { Gravel, sand, and } \\
\text { mudstone }\end{array}$ & Permeable \\
\hline & & Quaternary & Alluvial fan & Qay & Stream deposits & Permeable \\
\hline & & Quaternary & Slope debris & Qym & Slope debris & Permeable \\
\hline & & Quaternary & Old alluvial deposits & Qeal & Old alluvial deposits & Permeable \\
\hline & & Plio-Quaternary & Kepeztepe & $\mathrm{plQk}$ & $\begin{array}{l}\text { Old slope debris and } \\
\text { alluvial sediments }\end{array}$ & Permeable \\
\hline & & Late Miocene & Göksöğüt & Tmg & $\begin{array}{l}\text { Sandstone, claystone, } \\
\text { siltstone, marl, } \\
\text { clayey limestone }\end{array}$ & Semi-permeable \\
\hline & & Middle Miocene & Yarıkkaya & Tmy & $\begin{array}{l}\text { Claystone, mudstone, } \\
\text { clayey limestone } \\
\text { (lignite level) }\end{array}$ & Slight-permeable \\
\hline & & Middle Miocene & Limestone member & Tmyk & Limestone & Permeable-karstic \\
\hline & & $\begin{array}{l}\text { Middle-Late Mio- } \\
\text { cene }\end{array}$ & Bağkonak & $\mathrm{Tmb}$ & $\begin{array}{l}\text { Conglomerate, sand- } \\
\text { stone, marl, clay- } \\
\text { stone, mudstone }\end{array}$ & Semi-permeable \\
\hline \multirow[t]{5}{*}{$\begin{array}{l}\text { Beyşehir-Hoyran- } \\
\text { Hadim Nappes }\end{array}$} & Domuzdağ Nappe & $\begin{array}{l}\text { Middle Triassic- } \\
\text { Liassic }\end{array}$ & Dutdere & TRJd & Neritic limestone & Permeable-karstic \\
\hline & & Middle-late triassic & Bakırdağ & $\mathrm{TRb}$ & Limestone, dolomite & Permeable-karstic \\
\hline & Marmaris ophiolitic & Cretaceous & Marmaris peridotite & $\mathrm{Kmp}$ & $\begin{array}{l}\text { Harzburgites, dunite, } \\
\text { serpentine }\end{array}$ & Impermeable \\
\hline & Çay Unit & $\begin{array}{l}\text { Late Devonian-early- } \\
\text { middle carbonifer- } \\
\text { ous }\end{array}$ & Değirmendere & Dcd & $\begin{array}{l}\text { Chlorite schists, } \\
\text { sericite schists, } \\
\text { quartz schists, slate }\end{array}$ & Impermeable \\
\hline & & Middle eocene & Gölgeli & Teg & $\begin{array}{l}\text { Sandstone, claystone, } \\
\text { siltstone, marl, } \\
\text { conglomerate }\end{array}$ & Slight-permeable \\
\hline \multirow[t]{8}{*}{$\begin{array}{l}\text { Anamas-Akseki } \\
\text { autochthon }\end{array}$} & Sultandağ Unit & $\begin{array}{l}\text { Dogger-late Creta- } \\
\text { ceous }\end{array}$ & Hacialabaz & $\mathrm{JKh}$ & $\begin{array}{l}\text { Limestone, dolomite, } \\
\text { dolomitic lime- } \\
\text { stone }\end{array}$ & Permeable-karstic \\
\hline & & $\begin{array}{l}\text { Dogger-late Creta- } \\
\text { ceous }\end{array}$ & Düzkaya member & JKhd & $\begin{array}{l}\text { Spilite, basalt, } \\
\text { diabase }\end{array}$ & Impermeable \\
\hline & & $\begin{array}{l}\text { Middle Liassic- } \\
\text { Cenomanian }\end{array}$ & Kurucaova & $\mathrm{JKk}$ & $\begin{array}{c}\text { Neritic limestone, } \\
\text { dolomitic lime- } \\
\text { stone, dolomite }\end{array}$ & Permeable-karstic \\
\hline & & Malm & Ergenli & $\mathrm{Je}$ & Neritic limestone & Permeable-karstic \\
\hline & & $\begin{array}{l}\text { Late Cambrian-Early } \\
\text { Ordovician }\end{array}$ & Seydişehir & $\varepsilon \mathrm{Os}$ & $\begin{array}{l}\text { Metashale, } \\
\text { metasandstone, } \\
\text { nodular limestone, } \\
\text { quartzite, dolomite }\end{array}$ & Impermeable \\
\hline & & Cambrian & Çaltepe & $\varepsilon c ̧$ & $\begin{array}{l}\text { Limestone, dolomite } \\
\text { and nodular lime- } \\
\text { stone }\end{array}$ & Permeable-karstic \\
\hline & & Early Cambrian & Hüdai quartzite & $\varepsilon \mathrm{h}$ & Quartzite & Impermeable \\
\hline & & Precambrian & Gökoluk & peg & $\begin{array}{l}\text { Schist, quartzite, } \\
\text { slate, dolomite }\end{array}$ & Impermeable \\
\hline
\end{tabular}

northeast of Bağkonak village is discharged from the contact of Seydişehir and Hacıalabaz formations (Fig. 2). The yield of the spring is between 50 and 73 1/s (Soyaslan 2004). Özbayat Suçıkan Spring is discharged from the contact of Seydişehir and Çaltepe formation in east of Özbayat village and its flow rate is between 75 and $110 \mathrm{l} / \mathrm{s}$. Çetince spring is discharged from the conglomerate and sandstone levels of Göksögüut formation. Dedeçam 

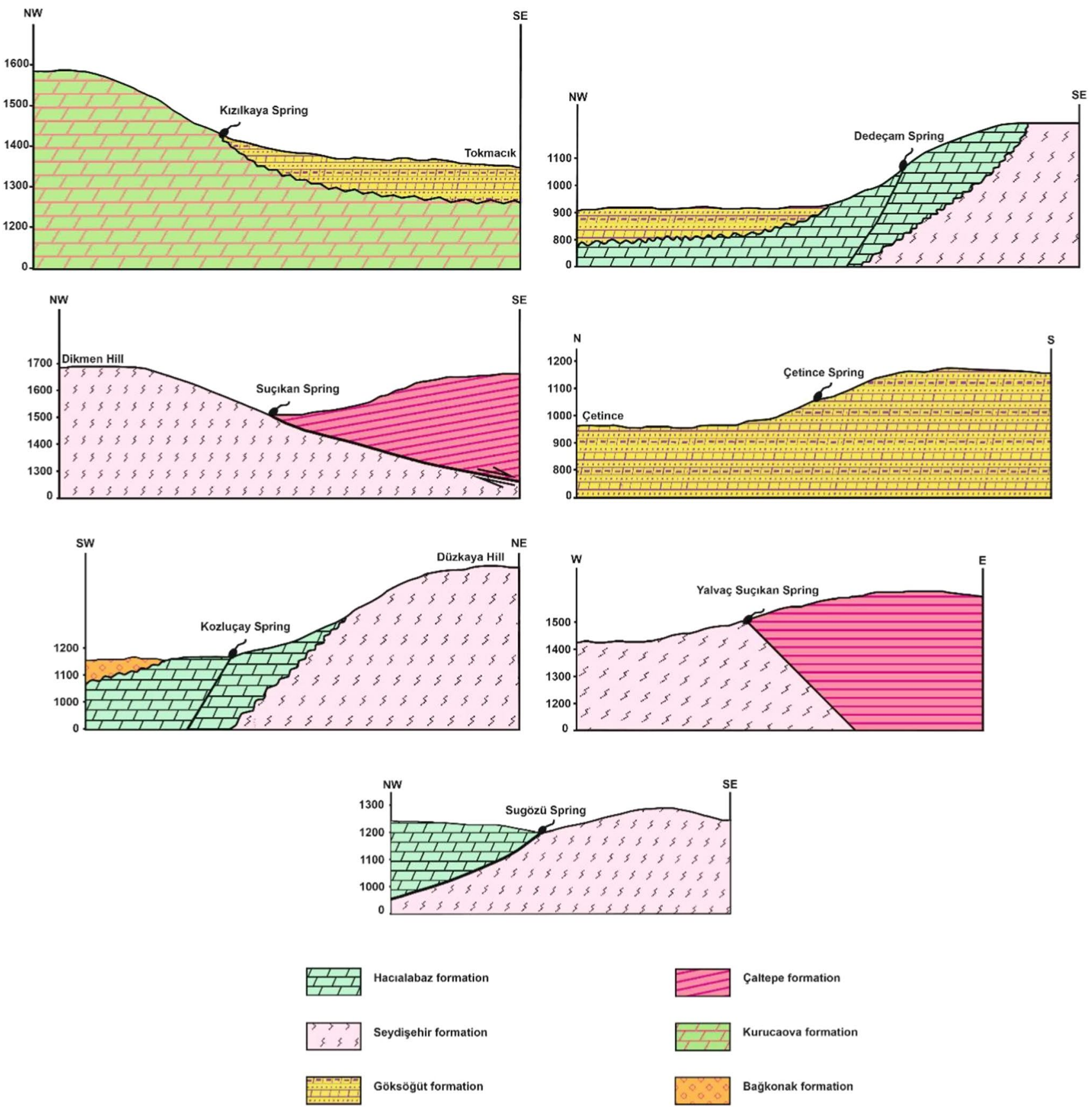

Fig. 2 Geological section of springs

Spring is discharged along the fault zone in limestones of Hacıalabaz formation. Tokmacık Kızılkaya spring discharged from the contact of Kurucaova and Göksögüt formations (Fig. 2). In addition, there are many seasonal springs discharged from limestones and Göksöğüt formation in the study area. 


\section{Materials and methods}

\section{Sampling and analysis}

Groundwater samples were collected in October-2019 and July-2017. Twenty-three water samples were gathered from drinking water resources (spring, well) in the Yalvaç-Gelendost basin. A global positioning system (GPS) equipment used for locating sampling points. Groundwater samples were collected in two polyethylene bottles. The samples were acidified ( $\mathrm{HNO} 3)$ to $<\mathrm{pH} 2$ for cation analysis. No action has been taken on water samples for anion analysis. The $\mathrm{pH}$, electrical conductivity (EC) and discharge temperature $\left(\mathrm{T}^{\circ} \mathrm{C}\right)$ of groundwaters were measured using a portable multiparameter HANNA (HI 991,301). Cations $\left(\mathrm{Na}^{+}, \mathrm{K}^{+}\right.$, $\mathrm{Ca}^{+2}, \mathrm{Mg}^{+2}$ ) and trace elements (such as $\mathrm{B}, \mathrm{Cr}, \mathrm{As}, \mathrm{Ba}, \mathrm{Mn}$, $\mathrm{Cu}, \mathrm{Zn}, \mathrm{Pb}$ ) were analyzed by using inductively coupled plasma-mass spectrometry (ICP-MS) at the Bureau Veritas Minerals Laboratories (BVML)/(Canada, an ISO 9002 accredited company). The anions $\left(\mathrm{Cl}^{-}, \mathrm{SO}_{4}{ }^{2-}, \mathrm{HCO}_{3}{ }^{-}\right.$, $\left.\mathrm{CO}_{3}{ }^{2-}\right), \mathrm{F}^{-}, \mathrm{NH}_{4}{ }^{+}, \mathrm{NO}_{3}{ }^{-}$and $\mathrm{NO}_{2}^{-}$were analyzed in the Süleyman Demirel University, Laboratory of Geological Engineering Department. AquaChem 2014.2 software program was used to evaluate the hydrogeochemical properties of waters. In addition, health risk assessment was carried out using the results of the chemical analysis of the waters. The hazard index (HI) approach that USEPA (1986) created based on the "Guidelines for Health Risk Assessment of Chemical Mixtures" was used in the analysis of health risks. Formulas and coefficients recommended by USEPA (2004) were used for carcinogenic and non-carcinogenic risk assessments.

\section{Results and discussion}

The hydrogeochemical analyses of groundwater samples (well and spring) of Yalvaç-Gelendost basin are presented in Table 2. Major ion chemistry, water types, saturation indices and hydrogeochemical processes of groundwater samples were identified. In addition, for the use of water samples as drinking water, water quality was evaluated with the standard guideline values as advised by WHO (2017) and health risk assessment was performed.

\section{Hydrogeochemical characteristics of groundwater}

\section{Major ions chemistry}

The $\mathrm{pH}$ value of groundwater in the study area ranges from 7.59-8.89 (Table 2), indicating that the dissolved carbonates are predominantly in the $\mathrm{HCO}_{3}{ }^{-}$form (Adams et al. 2001; Varol and Davraz 2016) and faintly alkaline nature. PH values of groundwater comply with WHO $(2011,2017)$ standards. The electrical conductivity (EC) value of spring waters and well waters in the study area varies between 230 and $420 \mu \mathrm{S} / \mathrm{cm}$ and $310-660 \mu \mathrm{S} / \mathrm{cm}$, respectively. The EC of the waters varies depending on the presence of ions, their total concentrations and temperature (Şahinci, 1991). The EC values of well waters are higher than spring waters due to prolonged contact with rocks. The ion content of spring waters varies during the circulation due to contact with rocks. The temperature $\left(\mathrm{T},{ }^{\circ} \mathrm{C}\right)$ of groundwaters in the study area varies $12.7-19.6^{\circ} \mathrm{C}$. All of the EC and T values of groundwater are suitable for drinking water standard of WHO $(2011,2017)$.

The $\mathrm{HCO}_{3}{ }^{-}$concentrations of groundwater were determined as 158.6 and $445.3 \mathrm{mg} / \mathrm{l}$. The most known model for $\mathrm{HCO}_{3}{ }^{-}$production in groundwaters is the dissolution of calcium carbonate by $\mathrm{CO}_{2}$ (Eq. 1). In this model, $\mathrm{HCO}_{3}{ }^{-}$and $\mathrm{Ca}$ will be released to groundwater during infiltration of rainwater. Similarly, silicate weathering also increases the concentration of $\mathrm{HCO}_{3}{ }^{-}$in groundwater (Elango and Kannan 2007).

$\mathrm{CO}_{2}+\mathrm{H}_{2} \mathrm{O}+\mathrm{CaCO}_{3} \rightleftarrows \mathrm{Ca}^{2+}+2 \mathrm{HCO}_{3}^{-}$

The $\mathrm{Ca}^{2+}$ concentrations varied for spring and well water as a range $24.56-99.34 \mathrm{mg} / \mathrm{l}$ and $44.96-124.5 \mathrm{mg} / \mathrm{l}$, respectively (Table 2). Calcium in groundwater is mostly found in calcite, dolomite, aragonite, anhydrite and gypsum minerals. In addition, the calcium ions can be derived from dissolution of amphibole and pyroxene groups, apatite, wollastonite, fluorite and some feldspars minerals. It is the secondary dominant cation in $\mathrm{Mg}^{2+}$ groundwater in the study area. The $\mathrm{Mg}^{2+}$ ions varied for spring and well water as a range $5.76-28.86 \mathrm{mg} / \mathrm{l}$ and $17.29-42.16 \mathrm{mg} / \mathrm{l}$, respectively (Table 2). The $\mathrm{Mg}^{2+}$ ion in groundwater originates mainly from dolomite mineral. In addition, magnesium is found in groundwater through igneous rock minerals (olivine, biotite, hornblende, augite), evaporite and metamorphic rock minerals (serpentine, talc, tremolite, diopside) (Singh et al. 2012). Hydrogeochemical processes controlling groundwater chemistry in the study area are discussed in detail in the following sections.

\section{Groundwater types}

The chemical character of water in hydrologic systems has been determined with the concept of hydrochemical facies (Back 1966). The hydrochemical facies reflect the effects of hydrochemical processes occurring between the minerals within the rocks and groundwater (Sajil Kumar 2013). The concept of hydrochemical facies has been widely used in many studies for chemical assessment of groundwater 
Table 2 Summary statistics of physical, chemical and pollution parameters of waters

\begin{tabular}{|c|c|c|c|c|c|c|}
\hline Parameter & Units & Minimum & Maximum & Average & Standard deviation & WHO (2017) \\
\hline \multicolumn{7}{|c|}{ October-2019 } \\
\hline \multicolumn{7}{|c|}{ Insitu measurements } \\
\hline $\mathrm{pH}$ & & 7.59 & 8.89 & 8.26 & 0.40 & \multirow[t]{3}{*}{$6.5-8.5$} \\
\hline $\mathrm{T}$ & ${ }^{\circ} \mathrm{C}$ & 12.6 & 19.6 & 14.8 & 2.17 & \\
\hline $\mathrm{EC}$ & $\mu \mathrm{S} / \mathrm{cm}$ & 230 & 660 & 376 & 121.37 & \\
\hline TDS & $\mathrm{mg} / \mathrm{l}$ & 100 & 330 & 182.66 & 64.75 & $600-1000$ \\
\hline \multicolumn{7}{|c|}{ Major elements } \\
\hline $\mathrm{Na}^{+}$ & $\mathrm{mg} / \mathrm{l}$ & 1.65 & 27.85 & 6.48 & 7.08 & \multirow[t]{4}{*}{200} \\
\hline $\mathrm{Ca}^{2+}$ & $\mathrm{mg} / \mathrm{l}$ & 24.56 & 124.50 & 56.12 & 27.17 & \\
\hline $\mathrm{K}^{+}$ & $\mathrm{mg} / \mathrm{l}$ & 0.22 & 2.02 & 0.91 & 0.55 & \\
\hline $\mathrm{Mg}^{2+}$ & $\mathrm{mg} / \mathrm{l}$ & 5.76 & 42.16 & 19.57 & 7.08 & \\
\hline $\mathrm{Cl}^{-}$ & $\mathrm{mg} / \mathrm{l}$ & 0.64 & 27.20 & 5.96 & 7.90 & 250 \\
\hline $\mathrm{SO}_{4}^{2-}$ & $\mathrm{mg} / \mathrm{l}$ & 3.11 & 40.63 & 13.16 & 11.75 & 500 \\
\hline $\mathrm{HCO}_{3}^{-}$ & $\mathrm{mg} / \mathrm{l}$ & 158.60 & 445.30 & 285.89 & 81.31 & \\
\hline $\mathrm{F}^{-}$ & $\mathrm{mg} / \mathrm{l}$ & 0.02 & 3.5 & 0.36 & 0.85 & 1.5 \\
\hline \multicolumn{7}{|l|}{ Nutrients } \\
\hline $\mathrm{NO}_{3}^{-}$ & $\mathrm{mg} / \mathrm{l}$ & 0.73 & 41.3 & 7.28 & \multirow[t]{3}{*}{9.68} & 50 \\
\hline $\mathrm{NO}_{2}^{-}$ & $\mathrm{mg} / \mathrm{l}$ & 0.01 & 0.01 & 0.01 & & 3 \\
\hline $\mathrm{NH}_{4}^{+}$ & $\mathrm{mg} / \mathrm{l}$ & 0.06 & 0.06 & 0.06 & & - \\
\hline \multicolumn{7}{|c|}{ Trace elements } \\
\hline As & $\mu \mathrm{g} / \mathrm{l}$ & 1.9 & 6.9 & 4.76 & 1.59 & 10 \\
\hline B & $\mu \mathrm{g} / \mathrm{l}$ & 5 & 43 & 15.87 & 14.20 & 2400 \\
\hline $\mathrm{Ba}$ & $\mu \mathrm{g} / \mathrm{l}$ & 18.7 & 490.97 & 146.64 & 119.57 & 1300 \\
\hline $\mathrm{Cr}$ & $\mu \mathrm{g} / 1$ & 0.6 & 6.3 & 1.55 & 1.45 & 50 \\
\hline $\mathrm{Cu}$ & $\mu \mathrm{g} / \mathrm{l}$ & 0.3 & 12.3 & 3.87 & 3.59 & 2000 \\
\hline $\mathrm{Mn}$ & $\mu \mathrm{g} / \mathrm{l}$ & 0.05 & 4.96 & 0.74 & 1.26 & 400 \\
\hline $\mathrm{Pb}$ & $\mu \mathrm{g} / 1$ & 0.018 & 0.9 & 0.23 & 0.26 & 10 \\
\hline $\mathrm{U}$ & $\mu \mathrm{g} / 1$ & 0.25 & 3.55 & 1.42 & 1.12 & 30 \\
\hline $\mathrm{Zn}$ & $\mu \mathrm{g} / \mathrm{l}$ & 0.7 & 27.9 & 7.02 & 7.09 & 5000 \\
\hline \multicolumn{7}{|l|}{ July-2017 } \\
\hline \multicolumn{7}{|c|}{ Insitu measurements } \\
\hline $\mathrm{pH}$ & & 7.17 & 8.21 & 7.85 & 0.32 & \multirow[t]{3}{*}{$6.5-8.5$} \\
\hline $\mathrm{T}$ & ${ }^{\circ} \mathrm{C}$ & 13.4 & 17.8 & 15.63 & 1.43 & \\
\hline $\mathrm{EC}$ & $\mu \mathrm{S} / \mathrm{cm}$ & 190 & 600 & 277.14 & 134.20 & \\
\hline TDS & $\mathrm{mg} / \mathrm{l}$ & 100 & 300 & 144.28 & 64.77 & $600-1000$ \\
\hline \multicolumn{7}{|c|}{ Major elements } \\
\hline $\mathrm{Na}^{+}$ & $\mathrm{mg} / \mathrm{l}$ & 1.68 & 14.25 & 3.91 & 4.27 & \multirow[t]{4}{*}{200} \\
\hline $\mathrm{Ca}^{2+}$ & $\mathrm{mg} / \mathrm{l}$ & 29.08 & 109.26 & 45.87 & 26.93 & \\
\hline $\mathrm{K}^{+}$ & $\mathrm{mg} / \mathrm{l}$ & 0.28 & 0.74 & 0.42 & 0.14 & \\
\hline $\mathrm{Mg}^{2+}$ & $\mathrm{mg} / \mathrm{l}$ & 10 & 20.31 & 13.15 & 3.23 & \\
\hline $\mathrm{Cl}^{-}$ & $\mathrm{mg} / \mathrm{l}$ & 0.87 & 10.78 & 2.94 & 3.35 & 250 \\
\hline $\mathrm{SO}_{4}^{2-}$ & $\mathrm{mg} / \mathrm{l}$ & 2.83 & 28.2 & 10.00 & 8.60 & 500 \\
\hline $\mathrm{HCO}_{3}^{-}$ & $\mathrm{mg} / \mathrm{l}$ & 137.55 & 400.69 & 187.10 & 88.86 & \\
\hline $\mathrm{F}^{-}$ & $\mathrm{mg} / \mathrm{l}$ & 0.01 & 0.17 & 0.06 & 0,046 & 1.5 \\
\hline \multicolumn{7}{|l|}{ Nutrients } \\
\hline $\mathrm{NO}_{3}^{-}$ & $\mathrm{mg} / \mathrm{l}$ & 0.98 & 17.09 & 3.83 & 5.42 & 50 \\
\hline $\mathrm{NO}_{2}^{-}$ & $\mathrm{mg} / \mathrm{l}$ & 0 & 0 & 0 & & 3 \\
\hline $\mathrm{NH}_{4}^{+}$ & $\mathrm{mg} / \mathrm{l}$ & 0 & 0.08 & 0.04 & 0.025 & - \\
\hline \multicolumn{7}{|c|}{ Trace elements } \\
\hline As & $\mu \mathrm{g} / \mathrm{l}$ & 9.3 & 14.7 & 11.36 & 1.77 & 10 \\
\hline B & $\mu \mathrm{g} / \mathrm{l}$ & 5 & 29 & 8.43 & 8.39 & 2400 \\
\hline
\end{tabular}


Table 2 (continued)

\begin{tabular}{cllllll}
\hline Parameter & Units & Minimum & Maximum & Average & Standard deviation & WHO (2017) \\
\hline $\mathrm{Ba}$ & $\mu \mathrm{g} / \mathrm{l}$ & 19.45 & 192.77 & 155.77 & 201.19 & 1300 \\
$\mathrm{Cr}$ & $\mu \mathrm{g} / \mathrm{l}$ & 1.7 & 2.3 & 1.89 & 0.18 & 50 \\
$\mathrm{Cu}$ & $\mu \mathrm{g} / \mathrm{l}$ & 0.5 & 3.9 & 1.71 & 1.10 & 2000 \\
$\mathrm{Mn}$ & $\mu \mathrm{g} / \mathrm{l}$ & 0.75 & 3.74 & 1.58 & 0.98 & 400 \\
$\mathrm{~Pb}$ & $\mu \mathrm{g} / \mathrm{l}$ & 0.2 & 0.5 & 0.31 & 0.12 & 10 \\
$\mathrm{U}$ & $\mu \mathrm{g} / \mathrm{l}$ & 0.28 & 3.83 & 0.82 & 1.23 & 30 \\
$\mathrm{Zn}$ & $\mu \mathrm{g} / \mathrm{l}$ & 1.3 & 15.5 & 5.75 & 4.33 & 5000 \\
\hline
\end{tabular}

and surface water. Piper (1944) and Durov (1948) proposed the first graphical applications used in the determination of hydrogeochemical facies of water. Both the diagrams reveal differences and similarities among water samples. In Piper diagram, the water type/hydrochemical facies in a water sample determine with plotting on the subdivisions of diamond-shaped field. In the Durov diagram, intersection of lines extended from the points in ternary diagrams and projected on the subdivisions of binary plot defines the hydrochemical processes related to the water type (Ravikumar et al. 2015).

In this study, Piper and Durov diagrams were used to assess the geochemical processes controlling the water chemistry and to delineate variation in hydrochemical facies. According to the Piper diagram, all well and spring water samples in the study area generally have similar structures. The dominant water type is $\mathrm{Ca}-\mathrm{Mg}-\mathrm{HCO}_{3}$ in the basin
(Fig. 3). Other water types in the basin are $\mathrm{Mg}-\mathrm{Ca}-\mathrm{HCO}_{3}$ and $\mathrm{Ca}-\mathrm{HCO}_{3}$. The $\mathrm{Mg}$ increase in some samples is due to the rock-water interaction in relation to the Kurucaova formation consisting of dolomitic limestones. In addition, the increase of $\mathrm{Mg}^{2+}$ in a spring water is associated with the Göksöğüt formation consisting of conglomerate, sandstone, claystone and marl units.

The Durov diagram is one of the most widely used forms of trilinear graphical representation for hydrochemical data. In this diagram, several parameters such as the total dissolved solids (TDS) and the $\mathrm{pH}$ can be shown in the remaining sides of the main rectangular field. Durov diagram is used to represent of the hydrochemical data and also helps to identify reasonable hydrogeochemical processes that dominate groundwater chemistry. Lloyd and Heathcote (1985) stated that the Durov diagram is useful in discerning processes that control the chemical properties of groundwater.

Fig. 3 Piper diagram

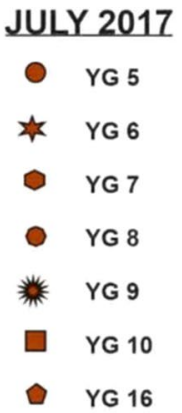

OCTOBER 2019

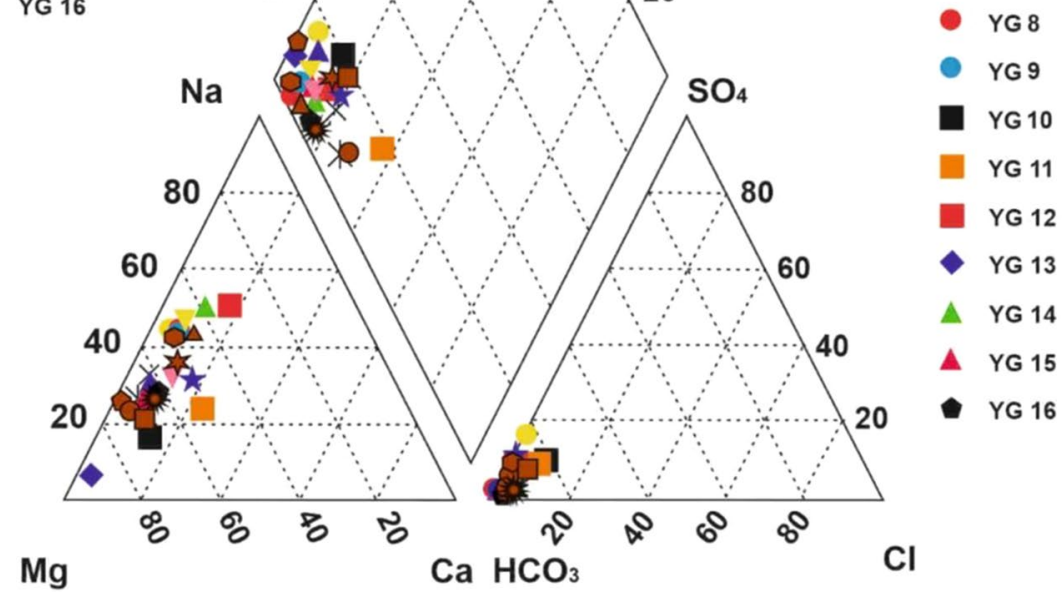


Table 3 Classification of water based on Durov diagram (Lloyd and Heathcote, 1985)

Water types

$1 \quad \mathrm{HCO}_{3}$ and $\mathrm{Ca}$ dominant, frequently indicates recharging waters in limestone, sandstone and many other aquifers

2 This water type is dominated by $\mathrm{Ca}$ and $\mathrm{HCO}_{3}$ ions. Association with dolomite is presumed if $\mathrm{Mg}$ is significant. However, those samples in which $\mathrm{Na}$ is significant, an important ion exchange is presumed

$3 \mathrm{HCO}_{3}$ and $\mathrm{Na}$ are dominant, normally indicates ion exchanged water, although the generation of $\mathrm{CO}_{2}$ at depth can produce $\mathrm{HCO}_{3}$ where $\mathrm{Na}$ is dominant under certain circumstances

$4 \mathrm{SO}_{4}$ dominates, or anion discriminant and $\mathrm{Ca}$ dominant, $\mathrm{Ca}$ and $\mathrm{SO}_{4}$ dominant, frequently indicates recharge water in lava and gypsiferous deposits, otherwise mixed water or water exhibiting simple dissolution may be indicated

5 No dominant anion or cation indicates water exhibiting simple dissolution or mixing

$6 \mathrm{SO}_{4}$ dominant or anion discriminate and $\mathrm{Na}$ dominant; is a water type that is not frequently encountered and indicates probable mixing or uncommon dissolution influences

$7 \mathrm{Cl}$ and $\mathrm{Na}$ dominant is frequently encountered unless cement pollution is present. Otherwise the water may result from reverse ion exchange of $\mathrm{Na}-\mathrm{Cl}$ waters

$8 \mathrm{Cl}$ dominant anion and $\mathrm{Na}$ dominant cation indicate that the ground waters be related to reverse ion exchange of $\mathrm{Na}-\mathrm{Cl}$ waters

$9 \mathrm{Cl}$ and $\mathrm{Na}$ dominant frequently indicate end-point down gradient waters through dissolution

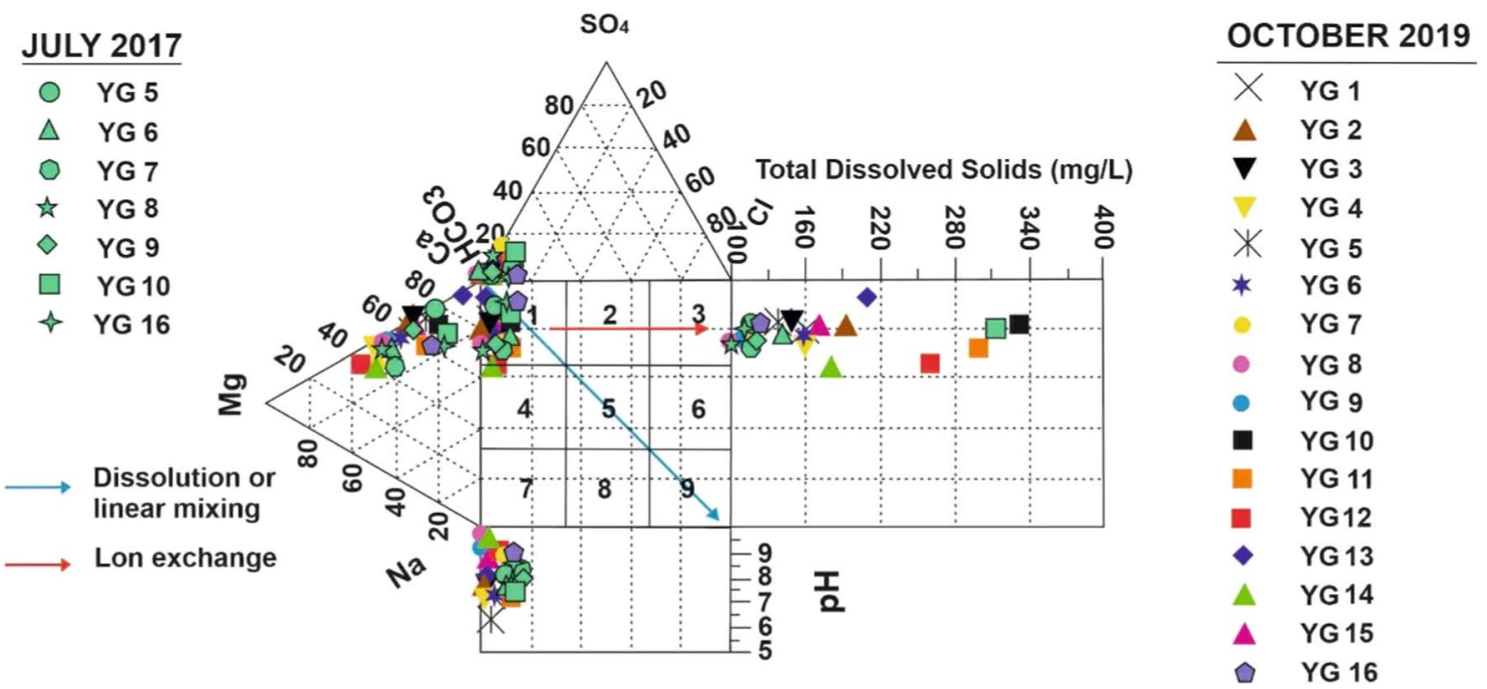

Fig. 4 Durov diagram

They have identified nine subfields on the Durov diagram. These areas contain information about aquifer environment and the hydrogeochemical processes that control water types (Table 3). Groundwater samples of the Yalvaç-Gelendost basin were plotted into the expanded Durov diagram shown in Fig. 4. Most water samples were grouped within the field 1. Only two samples are in field 4 (Fig. 4). Field 1 represents $\mathrm{HCO}_{3}{ }^{-}$and $\mathrm{Ca}^{2+}$ dominant ions in water and aquifers units are generally limestone and sandstone. Fields 1 and 4 define ion exchange process.

\section{Identification of hydrogeochemical processes}

The reactions between aquifer minerals and groundwater control the hydrogeochemical properties of water, and this is useful in understanding the source of groundwater. Major ions are a significant part of the total dissolved solids in groundwater. The concentrations of these ions in groundwater depend on the hydrogeochemical processes taking place in the aquifer system. These processes occur when groundwater reaches equilibrium in major ion concentrations (Lakshmanan et al. 2003). For this reason, the investigation of the concentrations of various major ions in groundwater used to identify geochemical processes.

Weathering, ion exchange processes and inputs from atmospheric and anthropogenic sources are the main solute uptake mechanisms that control the content of chemical components in groundwater. Depending on the abundance and solubility of ions in aquifer environments, the ion contents in groundwater change. The Gibbs (1970) diagram 
Fig. 5 Gibbs's diagrams
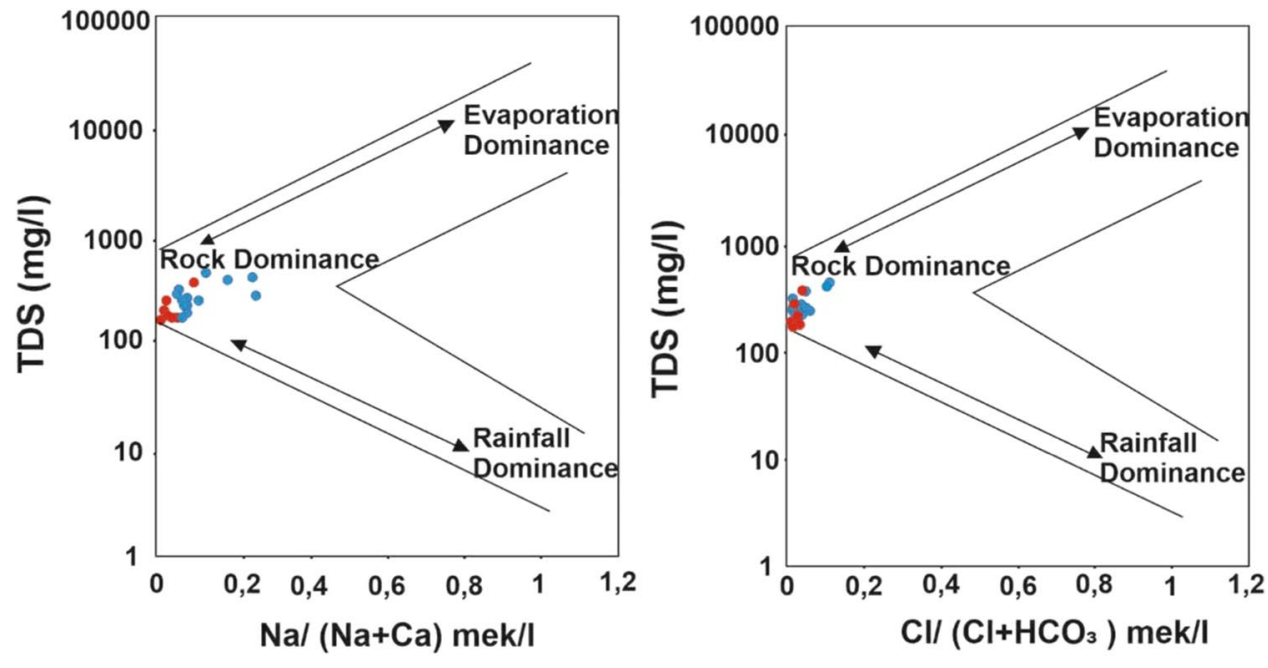

- October 2019

- July 2017

describes the composition and origin in the structure of water using ionic ratios in water. Gibbs diagram represents the ratio of $\mathrm{Cl}^{-} / \mathrm{Cl}^{-}+\mathrm{HCO}_{3}{ }^{-}$(Gibbs ratio $\mathrm{I}=$ for anions) and $\mathrm{Na}^{+}+\mathrm{K}^{+} / \mathrm{Na}^{+}+\mathrm{K}^{+}+\mathrm{Ca}^{2+}$ (Gibbs ratio $\mathrm{II}=$ for cations) as a function of TDS (Gibbs 1970; Fig. 5a,b). This diagram describes the possible sources of chemical compounds found dissolved in water. The groundwater samples taken from the study area are located in the "rock dominance" region on the Gibbs diagram. This shows that the main factor controlling groundwater chemistry is the rock-water interaction (Fig. 5).

It is impossible to control the dissolution of ion compounds when the waters are infiltrating underground. However, chemical changes of water can understood during circulation (Johnson 1979). Possible hydrogeochemical processes that control the chemical structure of groundwater are described in below. These processes are weathering and dissolution (carbonate weathering-silicate weathering), ion exchange and evaporation.

\section{Weathering and dissolution}

The origin of ions dissolved in groundwater can be evaluated by the content of ions, their ion ratios and the abundance of ions. The ionic concentrations variations of groundwater can easily be understand with different $\mathrm{X}-\mathrm{Y}$ coordinate graphs or ratios of ions with different resolutions, and hydrogeochemical processes in the aquifer environment can defined (Guler et al. 2002; Aghazadeh and Mogaddam 2011).
The weathering and dissolution of minerals can be interpreted simply by the graph of $\left(\mathrm{Ca}^{2+}+\mathrm{Mg}^{2+}\right)-\left(\mathrm{HCO}_{3}{ }^{-}+\mathrm{SO}_{4}{ }^{2-}\right)$. If the groundwater samples fall along the 1:1 line in this scatter plot, it indicates the weathering of carbonate and silicate in groundwater (Kuldip et al. 2011).

In a groundwater system where solubility of dolomite, calcite and gypsum is dominant, water samples will be close to the $1: 1$ line. The excess of $\mathrm{SO}_{4}{ }^{2-}+\mathrm{HCO}_{3}{ }^{-}$in the water causes the points to shift to the right, which reflects the ion exchange (Datta and Tyagi 1996).

The chemical data of the groundwater samples of the investigation area were illustrated in $\left(\mathrm{Ca}^{2+}+\mathrm{Mg}^{2+}\right)$ versus $\left(\mathrm{HCO}_{3}{ }^{-}+\mathrm{SO}_{4}{ }^{2-}\right)$ diagram (Fig. 6a). The majority of the sampling points fall below the equiline (1:1). This situation shows that silicate weathering is dominant processes in the aquifer system. Silicate weathering may indicate that $\mathrm{Na}$ decreases in groundwater and $\mathrm{HCO}_{3}{ }^{-}$ion increases due to ion exchange process. The presence of $\mathrm{Na}^{+}$and $\mathrm{K}^{+}$ ions in groundwater can be associated with the weathering of K-feldspar and Na-feldspar (albite). In silicate rocks, feldspars are more sensitive to alteration and weathering than quartz (Kumar et al. 2009).

The hydrochemistry of silicate weathering (weathering of albite to kaolinite) as presented in Eq. 2. Bicarbonate ion is produced by silicate weathering reactions (Tay 2012). This explains dominant $\mathrm{HCO}_{3}{ }^{-}$content in the groundwaters of the investigation area.

$2 \mathrm{NaAlSi}_{3} \mathrm{O}_{8}+2 \mathrm{CO}_{2}+11 \mathrm{H}_{2} \mathrm{O}=\mathrm{Al}_{2} \mathrm{Si}_{2} \mathrm{O}_{5}(\mathrm{OH})_{4}+2 \mathrm{Na}^{+}+2 \mathrm{HCO}_{3}^{-}+4 \mathrm{H}_{4} \mathrm{SiO}_{4}$

(Albite)

(Kaolinite) 

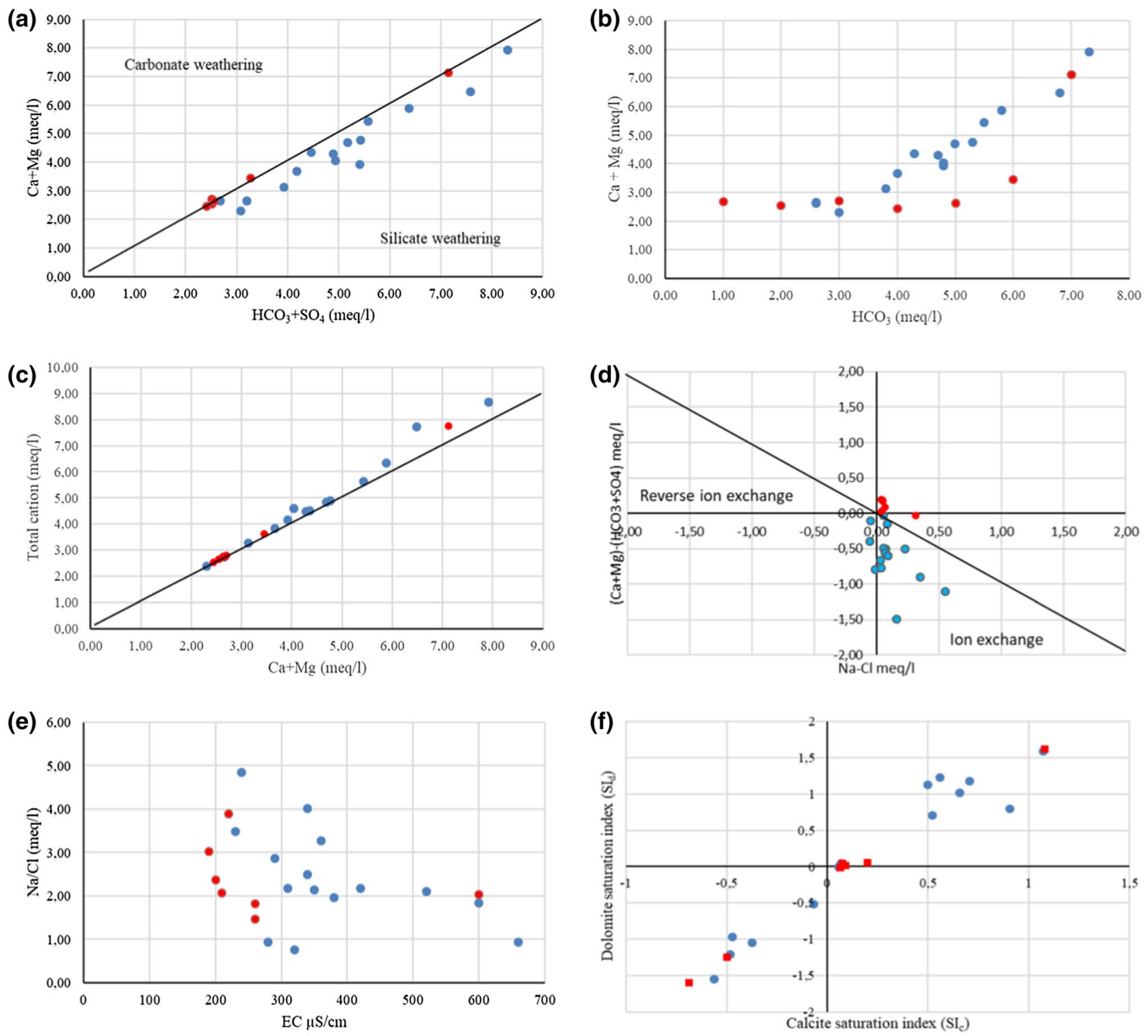

July-2017 October-2019

Fig. 6 Graphs of different parameters a scatter plot $\left(\mathrm{Ca}^{2+}+\mathrm{Mg}^{2+}\right)$ $\left(\mathrm{HCO}_{3}{ }^{-}+\mathrm{SO}_{4}{ }^{2-}\right) ; \quad$ b the scatter plot $\left(\mathrm{Ca}^{2+}+\mathrm{Mg}^{2+}\right)-\left(\mathrm{HCO}_{3}{ }^{-}\right)$; c the scatter plot $\left(\mathrm{Ca}^{2+}+\mathrm{Mg}^{2+}\right)-\mathrm{TC}$; d The scatter plot of

$\left[\left(\mathrm{Ca}^{2+}+\mathrm{Mg}^{2+}\right)-\left(\mathrm{HCO}_{3}{ }^{-}+\mathrm{SO}_{4}{ }^{2-}\right)\right]-\left(\mathrm{Na}^{+}-\mathrm{Cl}^{-}\right)$; e scatter plot of $\mathrm{Na} /$ $\mathrm{Cl}-\mathrm{EC}(\mu \mathrm{mhos} / \mathrm{cm})$; $\mathbf{f}$ plot of saturation indices dolomite (SId) of versus calcite (SIc).

Weathering occurs during the passage of groundwater through sandstones and silicate rocks.

Sandstones contain quartz and K-feldspar grains in a matrix of calcite and clay (Hounslow 1995). Bicarbonate may be produce by during percolation of groundwater in sandstones with weathering (Tay 2012).

The $\mathrm{HCO}_{3}{ }^{-} / \mathrm{SiO}_{2}$ ratio of groundwater can indicate the species of weathering in aquifer media. If $\mathrm{HCO}_{3}{ }^{-} / \mathrm{SiO}_{2}$ ratio is less than 5 , indicates silicate weathering and if this ratio is greater than 10, indicates carbonate weathering process (Tay,

2012). The $\mathrm{HCO}_{3}{ }^{-} \mathrm{SiO}_{2}$ ratio of groundwater samples in the study area is below 5 (Table 4 ) and this ratio confirmed that the silicate weathering process is the major hydrogeochemical process within the aquifer units in the study area.

The $\mathrm{Ca}^{2+}+\mathrm{Mg}^{2+} / \mathrm{HCO}_{3}{ }^{-}$ratio of groundwater can provide information about weathering type. Values of this ratio greater than 1 indicate that carbonate weathering is dominant, while values of this ratio less than 1 indicate silicate weathering (Kumar Singh et al. 2012; Pazand et al. 2012). The points are below the 1:1 line in the graph of 
Table 4 Some ion ratios of groundwater

\begin{tabular}{|c|c|c|c|c|c|c|}
\hline No & $\mathrm{Ca} / \mathrm{Mg}$ & $\mathrm{Na} / \mathrm{Cl}$ & $\mathrm{HCO}_{3} / \mathrm{SiO}_{2}$ & $\mathrm{Ca}+\mathrm{Mg} / \mathrm{HCO}_{3}$ & CAI-I & CAI-II \\
\hline \multicolumn{7}{|c|}{ October-2019 } \\
\hline YG-1 & 1,65 & 0,77 & 2,34 & 1,01 & 0,11 & 0,00 \\
\hline YG-2 & 1,80 & 1,96 & 1,76 & 0,90 & $-2,37$ & $-0,02$ \\
\hline YG-3 & 1,58 & 2,17 & 1,43 & 0,92 & $-1,46$ & $-0,02$ \\
\hline YG-4 & 0,97 & 2,14 & 0,63 & 0,94 & $-1,77$ & $-0,02$ \\
\hline YG-5 & 2,54 & 0,94 & 2,35 & 0,82 & $-0,01$ & 0,00 \\
\hline YG-6 & 1,58 & 4,01 & 3,65 & 0,82 & $-3,27$ & $-0,03$ \\
\hline YG-7 & 1,20 & 4,84 & 1,89 & 1,01 & $-4,15$ & $-0,02$ \\
\hline YG-8 & 1,14 & 2,87 & 2,01 & 0,77 & $-2,14$ & $-0,02$ \\
\hline YG-9 & 1,23 & 3,49 & 1,68 & 1,02 & $-2,74$ & $-0,02$ \\
\hline YG-10 & 3,65 & 0,93 & 1,99 & 1,08 & 0,03 & 0,00 \\
\hline YG-11 & 2,34 & 1,83 & 1,48 & 0,95 & $-0,90$ & $-0,08$ \\
\hline YG-12 & 0,70 & 2,10 & 1,07 & 1,01 & $-1,18$ & $-0,04$ \\
\hline YG-13 & 10,46 & 2,18 & 1,41 & 0,99 & $-1,68$ & $-0,02$ \\
\hline YG-14 & 0,85 & 3,28 & 0,92 & 0,84 & $-2,53$ & $-0,08$ \\
\hline YG-15 & 2,15 & 2,50 & 2,38 & 0,91 & $-1,81$ & $-0,02$ \\
\hline YG-16 & 2,02 & 3,05 & 2,01 & 1,05 & $-2,25$ & $-0,02$ \\
\hline \multicolumn{7}{|c|}{ July-2017 } \\
\hline YG-5 & 3,20 & 1,47 & 2,20 & 1,10 & $-0,56$ & $-0,02$ \\
\hline YG-6 & 1,46 & 2,38 & 3,45 & 1,04 & $-1,67$ & $-0,02$ \\
\hline YG-7 & 1,35 & 3,90 & 1,92 & 1,17 & $-3,19$ & $-0,03$ \\
\hline YG-8 & 1,33 & 2,07 & 2,03 & 1,10 & $-1,32$ & $-0,02$ \\
\hline YG-9 & 1,81 & 1,82 & 1,71 & 1,04 & $-1,09$ & $-0,02$ \\
\hline YG-10 & 3,26 & 2,04 & 2,01 & 1,08 & $-1,10$ & $-0,05$ \\
\hline YG-16 & 2,01 & 3,03 & 1,98 & 1,19 & $-2,37$ & $-0,02$ \\
\hline
\end{tabular}

$\left(\mathrm{Ca}^{2+}+\mathrm{Mg}^{2+}\right) /\left(\mathrm{HCO}_{3}{ }^{-}\right)$, except for five samples (Fig. 6b). This shows that $\mathrm{Ca}^{2+}, \mathrm{Mg}^{2+}$ and high $\mathrm{HCO}_{3}{ }^{-}$sources were derived from non-carbonate sources and silicate weathering is dominant.

Potential hydrochemical behavior can also estimate from ratios between ions such as $\mathrm{Ca}^{2+} / \mathrm{Mg}^{2+}$ and $\mathrm{Na}^{+} /$ $\mathrm{Cl}^{-}$(Han et al. 2009). In the study area, $\mathrm{Ca}^{2+}, \mathrm{Mg}^{2+}$ and $\mathrm{HCO}_{3}$ are dominant ions in groundwater. The dominant $\mathrm{Ca}^{2+}$ and $\mathrm{Mg}^{2+}$ contents in groundwater are associated with the presence of carbonated rocks in the basin. Carbonate and silicate weathering controls for the presence of $\mathrm{Ca}^{2+}$ and $\mathrm{Mg}^{2+}$ in groundwater. In different studies, $\mathrm{Ca}^{2+} /$ $\mathrm{Mg}^{2+}$ ratios of water have been used to make comments about the solubility of calcite and dolomite. In general, if $\mathrm{Ca}^{2+} / \mathrm{Mg}^{2+}$ ratio is equal to 1 , the presence of dolomite dissolution is mentioned, and a higher ratio reflects the calcite contribution. $\mathrm{A} \mathrm{Ca}^{2+} / \mathrm{Mg}^{2+}$ ratio higher than 2 indicates that the calcium and magnesium contribution in groundwater occurs with the dissolution of silicate minerals (Katz et al. 1998; Han et al. 2009). The $\mathrm{Ca}^{2+} / \mathrm{Mg}^{2+}$ ratio of $33 \%$ of groundwater in the study area is greater than 2 (Table 4) and indicates that the secondary process providing $\mathrm{Ca}$ ions to groundwater is silicate weathering
(Datta and Tyagi 1996). However, it is seen that calcite and dolomite solubility is dominant in the investigation area.

Also, groundwater samples are on the 1:1 line on the graph of total cations (TC) with $\mathrm{Ca}^{2+}+\mathrm{Mg}^{2+}$ (Fig. 6c). It is indicates that some of these ions $\left(\mathrm{Ca}^{2+}+\mathrm{Mg}^{2+}\right)$ are resulted from the weathering of silicate minerals (Kumar et al. 2009).

\section{lon exchange}

The ion exchange between aquifer rocks and groundwater is one of the important factors controlling groundwater chemistry. The most common ion exchangers in the aquifer system are clay minerals. The ion exchange process can be explained by chloro-alkaline indexes $(\mathrm{CAI}-\mathrm{I}=[\mathrm{Cl}-(\mathrm{K}+\mathrm{Na})] /$ $\mathrm{Cl}, \mathrm{CAI}-\mathrm{II}=[\mathrm{Cl}-(\mathrm{K}+\mathrm{Na})] /\left(\mathrm{CO}_{3}+\mathrm{HCO}_{3}+\mathrm{SO}_{4}+\mathrm{NO}_{3}\right)$ given below (Schoeller 1967, 1977). Chloro-alkali indices are positive when there is an exchange of $\mathrm{Mg}^{2}+$ and $\mathrm{Ca}^{2}+$ ions in rock and $\mathrm{K}^{+}$and $\mathrm{Na}^{+}$ions in water. This situation indicates reverse ion exchange. If the chloro-alkali indices are negative, $\mathrm{Na}$ and $\mathrm{K}$ in aquifer exchanged $\mathrm{Ca}$ and $\mathrm{Mg}$ in water, indicating ion exchange phenomenon (Liu et al. 2015; Zaidi et al. 2015). The negative values indicate chloro-alkaline 
disequilibrium, and this reaction is known as cation-anion exchange reaction.

Calculated CAI-I and CAI-II indices of water samples in the study area are generally negative (Table 4). This situation shows that "ion exchange" is dominant in the region. In other words, the $\mathrm{Ca}^{2+}$ and $\mathrm{Mg}^{2+}$ in groundwater are exchanged with $\mathrm{Na}^{+}$and $\mathrm{K}^{+}$in reservoir rock (Subramani et al. 2010; Zaidi et al. 2019). The diagram of $\left[\left(\mathrm{Mg}^{2+}+\mathrm{Ca}^{2+}\right)-\left(\mathrm{SO}_{4}{ }^{2-}+\mathrm{HCO}_{3}{ }^{-}\right)\right] /\left(\mathrm{Na}^{+}-\mathrm{Cl}^{-}\right)$is used to evaluate ion exchange processes occurring in groundwater (Subramani et al. 2010; Zaidi et al. 2019). The majority of samples being in the ion exchange zone strongly support the dominant influence of ion exchange (Fig. 6d).

\section{Evaporation}

Evaporation is a common phenomenon that can be observed in the groundwater system. The $\mathrm{Na} / \mathrm{Cl}$ ratio can be use to describe of evaporation process in groundwater. Evaporation is directly proportional to the increase of total dissolved solids (TDS) of groundwater (Kumar et al. 2006; Mahaqi et al. 2020). In the Yalvaç-Gelendost basin, the $\mathrm{Na} / \mathrm{Cl}$ ratios of groundwater are generally greater than 1 (Table 4 ). If the $\mathrm{Na} / \mathrm{Cl}$ ratio is around or above 1 , it indicates that sodium is the order of groundwater samples is not completely straight (Fig. 6e). This shows that evaporation is not the main geochemical process that controls groundwater chemistry in the study area. The Gibbs diagram given in Fig. 6 confirms that evaporation is not a dominant process in this basin.

Correlation analysis can also use to determine the relationships between the origin and physicochemical properties of the elements dissolved in water samples (Azaza et al. 2011). Correlations between major ions of groundwater were determined by Spearman's correlation analysis (Table 5). The groundwater samples have a strong positive correlation between the electrical conductivity $(\mathrm{EC}-\mu \mathrm{S} / \mathrm{cm})$ and $\mathrm{Ca}^{2+}, \mathrm{K}^{+}$and $\mathrm{HCO}_{3}{ }^{-}$contents. In addition, there is a strong positive correlation between $\mathrm{HCO}_{3}{ }^{-}$and $\mathrm{Ca}^{2+}$ and $\mathrm{K}^{+}$ions, and a strong positive correlation between $\mathrm{Na}^{+}$and $\mathrm{Cl}^{-}$ions. The strong positive correlation between $\mathrm{HCO}_{3}{ }^{-}$and $\mathrm{K}^{+}$ions indicates that the elements controlling the chemical structure of groundwaters are associated with silicate weathering. In an example silicate weathering reaction, potassium feldspar forms kaolinite as secondary mineral. In such a reaction, $\mathrm{K}^{+}$ and $\mathrm{HCO}_{3}{ }^{-}$are dissolution products (Eq. 3). Na-feldspar (albite) and K-feldspar (orthoclase and microcline) are common in sand and clay in the alluvium aquifer, and $\mathrm{Na}^{+}-\mathrm{K}^{+}$ ions are added to groundwater as a result of their weathering.

$\mathrm{KAlSi}_{3} \mathrm{O}_{8}+2 \mathrm{CO}_{2}+11 \mathrm{H}_{2} \mathrm{O} \leftrightarrow \mathrm{Al}_{2} \mathrm{Si}_{2} \mathrm{O}_{5}(\mathrm{OH})_{4}+4 \mathrm{H}_{4} \mathrm{SiO}_{4(\mathrm{aq})}+2 K^{+}+2 \mathrm{HCO}_{3}^{-}$

$K$-feldspar

Kaolinite

attributed from silicate weathering related to ion exchange processes (Mayback 1987; Garcia et al, 2001; Kumar et al, 2006; Tay 2012). As a result of ion exchange, $\mathrm{Na}^{+}$ions in clay minerals are replaced with $\mathrm{Ca}^{2+}$ ions in groundwater in the basin.

If evaporation dominant, the groundwater's EC value will increase, while the $\mathrm{Na} / \mathrm{Cl}$ ratio will remain constant. Accordingly, $\mathrm{EC}$ ( $\mu \mathrm{mhos} / \mathrm{cm}$ ) versus $\mathrm{Na} / \mathrm{Cl}$ diagram should form a horizontal line (Jankowski and Acworth 1997; Chebboh and Allia 2015). On the Na/Cl-EC ( $\mu \mathrm{mhos} / \mathrm{cm}$ ) diagram,
The strong positive correlation between $\mathrm{HCO}_{3}{ }^{-}$and $\mathrm{Ca}^{2+}$ ions is associated with carbonate solubility (Eq. 4).

$\mathrm{CaCO}_{3}+\mathrm{H}_{2} \mathrm{CO}_{3} \leftrightarrow \mathrm{Ca}^{+2}+2 \mathrm{HCO}_{3}^{-}$

According to the correlation analysis, there is a moderate correlation between $\mathrm{Ca}^{2+}$ and $\mathrm{Na}^{+}, \mathrm{K}^{+}$and $\mathrm{Cl}^{-}$ions and between $\mathrm{Mg}^{2+}$ and $\mathrm{SO}_{4}{ }^{2-}$. This reflects similar source and/or geochemical behavior during ionic mobilization. There is a moderate positive correlation between $\mathrm{Na}^{+}$and $\mathrm{HCO}_{3}{ }^{-}$and
Table 5 Correlation analysis of major ions in groundwater

\begin{tabular}{|c|c|c|c|c|c|c|c|c|c|}
\hline & $\mathrm{pH}$ & EC & $\mathrm{Ca}$ & $\mathrm{Mg}$ & $\mathrm{Na}$ & $\mathrm{K}$ & $\mathrm{HCO}_{3}$ & $\mathrm{Cl}$ & $\mathrm{SO}_{4}$ \\
\hline $\mathrm{pH}$ & 1 & -0.106 & -0.456 & -0.09 & -0.18 & -0.220 & -0.214 & -0.288 & -0.356 \\
\hline $\mathrm{EC}$ & & 1 & 0.732 & 0.617 & 0.696 & 0.774 & 0.988 & 0.687 & 0.427 \\
\hline $\mathrm{Ca}$ & & & 1 & 0.212 & 0.503 & 0.665 & 0.756 & 0.610 & 0.350 \\
\hline $\mathrm{Mg}$ & & & & 1 & 0.490 & 0.482 & 0.614 & 0.411 & 0.563 \\
\hline $\mathrm{Na}$ & & & & & 1 & 0.415 & 0.688 & 0.862 & 0.661 \\
\hline K & & & & & & 1 & 0.754 & 0.479 & 0.083 \\
\hline $\mathrm{HCO}_{3}$ & & & & & & & 1 & 0.686 & 0.454 \\
\hline $\mathrm{Cl}$ & & & & & & & & 1 & 0.44 \\
\hline $\mathrm{SO}_{4}$ & & & & & & & & & 1 \\
\hline
\end{tabular}

Boldface are the values that exceed the limit values 
Table 6 The mineral saturation indexes of groundwater

\begin{tabular}{lllllllll}
\hline No & Anhydride & Aragonite & Barite & Calcite & Dolomite & Fluorite & Gypsum & Halite \\
\hline October-2019 & & & & & & & & \\
YG-1 & $-3,0858$ & 0,3676 & $-0,7939$ & 0,5205 & 0,7088 & $-3,2413$ & $-2,8331$ & $-9,1842$ \\
YG-2 & $-3,1769$ & 0,5562 & $-0,3655$ & 0,7061 & 1,1782 & $-2,3553$ & $-2,9313$ & $-10,2205$ \\
YG-3 & $-3,0048$ & $-0,524$ & $-0,2186$ & $-0,3747$ & $-1,0502$ & $-3,1399$ & $-2,7612$ & $-9,827$ \\
YG-4 & $-3,1187$ & $-0,6247$ & $-0,2294$ & $-0,4722$ & $-0,9696$ & $-2,5698$ & $-2,8668$ & $-9,9352$ \\
YG-5 & $-3,2327$ & $-0,715$ & $-0,4044$ & $-0,563$ & $-1,5549$ & $-4,0437$ & $-2,9819$ & $-9,3801$ \\
YG-6 & $-2,5573$ & $-0,6346$ & $-0,2294$ & $-0,4816$ & $-1,2083$ & $-3,089$ & $-2,3046$ & $-9,5707$ \\
YG-7 & $-2,7243$ & $-0,0951$ & $-0,1004$ & 0,0579 & $-0,0103$ & $-4,5633$ & $-2,4714$ & $-10,4159$ \\
YG-8 & $-3,6554$ & $-0,0834$ & $-1,2033$ & 0,0693 & 0,0408 & $-4,2681$ & $-3,4029$ & $-10,4464$ \\
YG-9 & $-3,5586$ & $-0,0771$ & $-1,176$ & 0,076 & 0,0127 & $-4,5413$ & $-3,3056$ & $-10,3196$ \\
YG-10 & $-2,0679$ & 0,9203 & 0,3594 & 1,071 & 1,5845 & 0,3791 & $-1,8202$ & $-7,92$ \\
YG-11 & $-2,2727$ & $-0,2209$ & 0,3507 & $-0,0698$ & $-0,5155$ & $-1,2158$ & $-2,0238$ & $-7,7481$ \\
YG-12 & $-2,6468$ & 0,4051 & $-0,0793$ & 0,5581 & 1,2285 & $-1,8471$ & $-2,394$ & $-8,6707$ \\
YG-13 & $-3,1589$ & 0,7568 & $-0,1971$ & 0,9074 & 0,8005 & $-4,1247$ & $-2,9111$ & $-9,5731$ \\
YG-14 & $-3,3012$ & 0,3499 & $-0,2369$ & 0,4976 & 1,1303 & $-3,3036$ & $-3,0629$ & $-8,752$ \\
YG-15 & $-2,9936$ & 0,5064 & $-0,5589$ & 0,6557 & 1,012 & $-4,9726$ & $-2,7497$ & $-9,6214$ \\
YG-16 & $-2,7586$ & $-0,0971$ & $-1,256$ & 0,1256 & 0,0256 & $-4,6587$ & $-3,3578$ & $-6,3896$ \\
July-2017 & & & & & & & & \\
YG-5 & $-3,1214$ & $-0,845$ & $-0,3978$ & $-0,689$ & $-1,5987$ & $-4,0587$ & $-3,0178$ & $-9,4012$ \\
YG-6 & $-2,3574$ & $-0,7125$ & $-0,2587$ & $-0,4978$ & $-1,2521$ & $-3,098$ & $-2,3698$ & $-9,6105$ \\
YG-7 & $-2,8291$ & $-0,0868$ & $-0,1154$ & 0,0634 & $-0,0121$ & $-4,6254$ & $-2,4915$ & $-10,4584$ \\
YG-8 & $-3,3587$ & $-0,0762$ & $-1,2258$ & 0,0745 & 0,0458 & $-4,3378$ & $-3,4532$ & $-10,4945$ \\
YG-9 & $-3,1354$ & $-0,0687$ & $-1,198$ & 0,0890 & 0,0135 & $-4,5974$ & $-3,3365$ & $-10,2186$ \\
YG-10 & $-1,9157$ & 0,9678 & 0,3798 & 1,0790 & 1,6178 & 0,4168 & $-1,8584$ & $-7,890$ \\
YG-16 & $-2,9850$ & $-0,125$ & $-1,378$ & 0,2015 & 0,0528 & $-4,5874$ & $-3,2547$ & $-5,8970$ \\
\hline & & & & & & & &
\end{tabular}

$\mathrm{SO}_{4}{ }^{2-}$. The correlation between $\mathrm{Na}^{+}$and $\mathrm{HCO}_{3}{ }^{-}$is also related to silicate weathering and is due to the weathering of albite to kaolinite (Eq. 2).

\section{Saturation index}

The most important factor controlling groundwater geochemistry is the dissolution-precipitation processes resulting from rock-water interaction. Ion exchange between groundwater and rocks which is in contact during the cycle causes changes in the chemical composition of the water. To identify the geochemical reactions that control water chemistry, the saturation states of various minerals are examined. Saturation indexes are used to evaluate the degree of equilibrium between water and minerals (Langmuir 1997; Aghazadeh and Mogaddam 2011; Kumar Singh et al. 2012). The saturation indexes (SI) of groundwater were determined using PHREEQC software (Parkhurst and Appelo 1999). Neutral $\mathrm{SI}(\mathrm{SI}=0)$ is in equilibrium state with the mineral phase. SI less than zero (or negative) indicates dissolution of mineral phase and undersaturation conditions. A positive SI value for a mineral indicates that groundwater is over-saturated with that mineral, and that the mineral in equilibrium may precipitate.

The mineral saturation indexes determined according to the discharge temperatures and $\mathrm{pH}$ values of groundwater are given in Table 6. All groundwater samples are under saturation with respect to gypsum, halite and anhydrite minerals, and they tend to dissolve. This indicates that the solubility of $\mathrm{Na}^{+}, \mathrm{Cl}^{-}$and $\mathrm{SO}_{4}{ }^{2-}$ ions in the reservoir still continues. Fluorite mineral is also undersaturated except for one sample (YG10). It is thought that the increase of F $(3.5 \mathrm{mg} / \mathrm{l})$ ion in this example is related to the Seydişehir formation, where the spring water is discharged. About $46 \%$ of the analyzed water samples are saturated with aragonite mineral.

The graph of saturation indices dolomite $\left(\mathrm{SI}_{\mathrm{d}}\right)$ of versus calcite $\left(\mathrm{SI}_{\mathrm{c}}\right)$ indicates that most of the groundwater samples are supersaturated with respect to calcite and dolomite (Fig. 6f). This shows that carbonate minerals are the main components in the aquifer environment and carbonate dissolution-precipitation processes continue. It is seen that the groundwater samples saturated with respect to calcite and dolomite minerals in the basin are related to the Kurucaova formation, which consists of limestone and dolomitic limestone lithologies. 


\section{Chemical quality of groundwaters}

The chemical quality of the groundwaters has been evaluated for drinking water use in the study area. The analysis results of major ions, trace elements and nitrogen derivatives of groundwaters were compared with the World Health Organization (WHO, 2017) and Turkey Regulation on Water Intended for Human Consumption (TS266, 2005). The $\mathrm{pH}$ of the groundwater samples is within acceptable drinking water limits (6.5-9.5) of TS266 (2005). No health-based guideline value is proposed by WHO (2017) for $\mathrm{pH}$. Although $\mathrm{pH}$ usually has no direct impact on consumers, it is one of the most important operational water quality parameters (WHO 2017). The analysis results of major ions $\left(\mathrm{Na}^{+}\right.$, $\left.K^{+}, \mathrm{Ca}^{+2}, \mathrm{Mg}^{+2}, \mathrm{Cl}^{-}, \mathrm{SO}_{4}{ }^{2-}, \mathrm{HCO}_{3}{ }^{-}\right)$, nitrogen derivatives $\left(\mathrm{NO}_{3}{ }^{-}, \mathrm{NO}_{2}{ }^{-}, \mathrm{NH}_{4}{ }^{+}\right)$and trace elements $(\mathrm{As}, \mathrm{B}, \mathrm{Ba}, \mathrm{Cr}$, $\mathrm{Cu}, \mathrm{Mn}, \mathrm{Pb}, \mathrm{Zn}$ ) of groundwaters do not exceed permissible limits. But, $\mathrm{F}^{-}$concentration of YG-10 sample exceeded the WHO $(2011,2017)$ and TS266 (2005) limit (1.5 mg/l). YG-10 sample belongs to well water of Yağcilar village. In this well, alluvium and Göksöğüt formation have been cut. Fluoride is present in most geological environments but particularly in igneous and sandstone rocks. Fluorides are found in groundwater through various fluoride-containing minerals due to water-rock interaction. Fluorine exists in the form of fluorides in a number of minerals, such as fluorspar, cryolite and fluorapatite (WHO 2017). The increase of F in the YG-10 groundwater sample may be related to the sandstones of the Göksöğüt formation. In addition, fluorapatite $\left(\mathrm{Ca}_{5}\left(\mathrm{PO}_{4}\right) 3 \mathrm{~F}\right)$ is used mostly for production of fertilizers. Also, agricultural anthropogenic sources may be effective in this increase.

The arsenic content of groundwater in the study area ranged from 9.3-14.7 $\mu \mathrm{g} / \mathrm{l}$ in July-2017 and 1.9-6.9 $\mu \mathrm{g} / \mathrm{l}$ in October-2019 (Table 2). For drinking water, the tolerable limit of As is $10 \mu \mathrm{g} / \mathrm{l}$ according to WHO (2017) and TS266 (2005) standards. The presence of arsenic in groundwater depends on local hydrogeology, geochemical properties of aquifers, climate changes and human activities (Wang and Mulligan 2006). The most common sources of arsenic in the natural environment are geothermal waters, hydrothermal ore deposits, marine sedimentary rocks, volcanic rocks (weathering products and ash), and fossil fuels (coals and petroleum levels). The main anthropogenic sources for arsenic are use of arsenical fungicides, herbicides and insecticides in agriculture, burning of fossil fuels, mining, wood preservatives and municipal and industrial wastes (Wang and Mulligan, 2006; Shankar et al. 2014).

Arsenic content of groundwater in the study area is related to rock-water interaction and agricultural activities. The arsenic content increased in the July 2017 samples representing the rainy period. This increase is as a result of the influence of water-rock interactions and the greater tendency in aquifers for the physical and geochemical conditions to be favorable for arsenic mobilization and accumulation. The variability of the arsenic concentration in groundwater is associated with the arsenic content of the aquifer and dissolution and desorption processes that release the arsenic from the solid phase to the liquid phase. The increase of arsenic in the aquifer environment is associated with the use of pesticides in the study area.

The nitrate content of groundwater samples varies between 0.73 and $41.3 \mathrm{mg} / \mathrm{l}$ in the study area (Table 2). The nitrate content $(41.3 \mathrm{mg} / \mathrm{l})$ of the YG-10 sample taken from well water approached the drinking water limit value of $50 \mathrm{mg} / \mathrm{l}$ (TS266, 2005; WHO, 2017). The nitrate content of YG-10 sample was determined as $17.9 \mathrm{mg} / \mathrm{l}$ in July 2017 representing the rainy period. The nitrate contents of groundwater samples do not exceeded the permissible values giving WHO (2017) and TS266 (2005). However, nitrate concentration values above $10 \mathrm{mg} / \mathrm{l}$ indicate anthropogenic pollution. Natural nitrate levels in groundwater are very low (generally $<10 \mathrm{mg} / \mathrm{l}$ ). However, nitrate concentrations in water increase with human activities, such as over fertilization of crop, cultivation of crops (corn, tobacco and vegetables) that require high fertilizer use, fertilizer transport with drainage systems, domestic wastewater and industry.

In this study, health risk assessment has been made for the parameters of $\mathrm{As}, \mathrm{F}$ and $\mathrm{NO}_{3}$, which may have a negative health effect by evaluating the groundwater samples in terms of drinking water quality.

\section{Human health risk assessment}

Today, lack of drinking water and drinking water-related health problems have become a global problem. Human life depends on healthy drinking water intake (WHO 2004). The presence of toxic pollutants such as microbiological and heavy metals that can found in drinking water is important risk for human health. Risk assessment is an attempt to identify and measure potential risks to human health from exposure to various pollutants (Kavcar et al. 2009; Davraz et al. 2016; Varol and Davraz 2016; Shukla and Saxena 2020).

\section{Exposure assessment}

The first step of the human health risk assessment is exposure assessment (Means 1989; USEPA 2001; Sarvestani and Aghasi 2019). The pollutants intake by human body through ingestion (oral), inhalation (inhalation) and skin contact. Ingestion and skin (dermal) absorption are common exposure conditions for drinking water (USEPA 2004; Wu et al. 2009; Li and Zhang 2010). In this study, exposure with ingestion and dermal (skin contact) routes is taken into consideration. 
Table 7 Default values for drinking water and dermal use (USEPA, 2001) and Kp, RfD, SF values (IRIS, 2005; USEPA, 2013)

\begin{tabular}{|c|c|c|c|c|c|}
\hline & Adult & Child & & & \\
\hline L (1/day) & 2 & 1 & & & \\
\hline \multirow[t]{2}{*}{ EF (gün/year) } & 365-oral & 365-oral & & & \\
\hline & 350-dermal & 350-dermal & & & \\
\hline ED (year) & 30 & 6 & & & \\
\hline $\mathrm{BW}(\mathrm{kg})$ & 70 & 15 & & & \\
\hline AT (day) & 10,950 & 2190 & & & \\
\hline $\mathrm{SA}\left(\mathrm{cm}^{2}\right)$ & 18,000 & 6600 & & & \\
\hline \multirow[t]{2}{*}{ ET (s/day) } & 2.6 & 1 & & & \\
\hline & & & As & $\mathrm{F}$ & $\mathrm{NO}_{3}$ \\
\hline \multicolumn{2}{|l|}{$\mathrm{Kp}(\mathrm{cm} / \mathrm{h})$} & & 0.001 & 0.001 & \\
\hline \multicolumn{2}{|c|}{ RfD-oral (mg/kg/d) } & & $3 \mathrm{E}-04$ & 0.06 & 1.6 \\
\hline \multicolumn{2}{|c|}{ RfD-dermal (mg/kg/d) } & & $1.23 \mathrm{E}-04$ & 0.06 & 0.8 \\
\hline \multicolumn{2}{|c|}{ SF-oral (kg d/mg) } & & 1.5 & & \\
\hline \multicolumn{2}{|c|}{ SF-dermal (kg d/mg) } & & 3.66 & & \\
\hline
\end{tabular}

$E D$ exposure duration, $E F$ exposure frequency, $L$ : daily water ingestion rate; $B W$ bodyweight, $A T$ average exposure time, $K p$ dermal permeability coefficient in water; $E T$ exposure time, $S A$ exposed skin area

To estimate the daily exposure of an individual, USEPA (2005) recommended a Lifelong Average Daily Dose (LADD) or Chronic Daily Intake (CDI) exposure calculation (Kavcar et al. 2009; Yu et al. 2014; Varol and Davraz 2016; Sarvestani and Aghasi 2019; Shukla and Saxena 2020). The average daily dose (ADD) through oral ingestion and dermal is calculated with the following formulas (USEPA 2004). The parameters recommended by USEPA (2001) in calculating the average daily dose (ADD) for drinking water and dermal (skin absorption such as bath, etc.) are given in Table 7.

$$
\mathrm{ADD}_{\text {oral ingestion }}=\left(C_{i} \times L \times \mathrm{EF} \times \mathrm{ED}\right) /(\mathrm{AT} \times \mathrm{BW})
$$

$$
\begin{aligned}
& \mathrm{ADD}_{\text {dermal }} \\
& \quad=\left(C \mathrm{i} \times K \mathrm{p} \times \mathrm{SA} \times \mathrm{EF} \times \mathrm{ET} \times \mathrm{ED} \times 10^{-3}\right) /(\mathrm{AT} \times \mathrm{BW})
\end{aligned}
$$

\section{Non-carcinogenic risk assessment}

The hazard index (HI) approach has been developed based on USEPA's (1986) "Health Risk Assessment Guidelines for Chemical Mixtures" to evaluate non-carcinogenic effects caused by multiple chemicals. The potential non-carcinogenic risk is calculated using the reference dose (RfD) value and the average daily dose (ADD) value which is calculated taking into account the route of contaminant absorption into the body, exposure time, grade and frequency (Eq. 7). The non-carcinogenic risk calculation for human health through multiple heavy metals can also be evaluated with the hazard index (HI), which is the sum of all HQs calculated for the individual heavy metal. RfD values provided from the EPA Health Effects Assessment summary tables (HEAST) (Table 7; USEPA 2013).

Hazard Quotient $(\mathrm{HQ})=\mathrm{ADD} / \mathrm{RfD}$

HQ or HI $>1$ values indicate that pollutants will have a negative impact on human health (USEPA 2001, 2004).

\section{Carcinogenic risk assessment}

The carcinogenic risk is calculated with the following formula using the average daily dose (ADD; $\mathrm{mg} / \mathrm{kg} \mathrm{d}$ ) and slope factor (SF; $\mathrm{kg} \mathrm{d} / \mathrm{mg}$ ) values. The acceptable risk is in the range of $10^{-6}$ to $10^{-4}$ (Asare-Donkor and Adimado 2020; Li and Zhang 2010; Lim et al. 2008). SF values (Table 7) provided in the integrated risk information system (IRIS) at the web site of USEPA (2013).

$R_{\text {cancer }}=\mathrm{ADD} \times \mathrm{SF}$

In this study, health risk calculations have been made for As, $\mathrm{NO}_{3}$ and $\mathrm{F}$ parameters that may pose health risks. The hazard quotient (HQ), hazard index (HI) and $R_{\text {cancer }}$ values for oral and dermal pathways relating to child and adult are presented in Tables 8 and 9. For child, hazard coefficient $\left(\mathrm{HQ}_{\text {oral }}\right)$ and hazard index values $\left(\mathrm{HI}_{\text {oral }}\right)$ calculated for As, $F$ and $\mathrm{NO}_{3}$ parameters for use as drinking water are less than 1 . Similarly, hazard coefficients $\left(\mathrm{HQ}_{\mathrm{dermal}}\right)$ and total hazard index (HI) calculated for parameters $\mathrm{As}, \mathrm{NO}_{3}$ and $F$, depending on skin exposure, are less than 1 (Table 8). It can be suggested that it will not have a negative effect on usage as drinking water and dermal (skin contact) absorption for child. For October-2019, cancer risk values for use as drinking water (oral) and dermal intake for As element are also within the tolerable risk range of $10^{-6}-10^{-4}$, for child (Table 8). But, carcinogenic risk of As with oral intake in July-2017 exceeded the permissible risk of $1 \times 10^{-4}$ (Table 8).

For adults, $\mathrm{HQs}_{\text {ingestion }}$ (hazard quotient by ingestion) values of As and $\mathrm{NO}_{3}$ were less than 1, suggesting that these elements posed little hazard in use as drinking water. However, $\mathrm{HQ}_{\text {ingestion }}$ of YG-10 (well water) sample for $\mathrm{F}$ element was more than 1 (1.67), implying that $F$ may cause adverse health effects and potential non-carcinogenic concern for adults. The hazard indexes (HI) of water samples except for YG-10, YG-11 and YG-16 samples were lower than 1.0 in October-2019 (Table 9). Potential non-carcinogenic effect is likely to occur for YG-10 and YG-11 samples which are taken from well waters for adults. The excess fluoride intake with drinking water can cause dental fluorosis, skeletal 
Table 8 Hazard index for each element and cancer risk of As for child

\begin{tabular}{|c|c|c|c|c|c|c|c|c|c|c|}
\hline & \multicolumn{5}{|c|}{ Child-HQ ${ }_{\text {oral }}$} & \multicolumn{5}{|c|}{ Child- $\mathrm{HQ}_{\text {dermal }}$} \\
\hline & As & $\mathrm{F}$ & $\mathrm{NO}_{3}$ & HI & As-Can.R & As & $\mathrm{F}$ & $\mathrm{NO}_{3}$ & HI & As-Can.R \\
\hline \multicolumn{11}{|c|}{ October-2019 } \\
\hline YG-1 & 3.07E-01 & $1.56 \mathrm{E}-02$ & $3.22 \mathrm{E}-02$ & $3.54 \mathrm{E}-01$ & 6.91E-04 & 2.37E-02 & 4.92E-04 & $2.04 \mathrm{E}-03$ & $2.62 \mathrm{E}-02$ & $1.07 \mathrm{E}-05$ \\
\hline YG-2 & 2.09E-01 & 8.89E-03 & 4.13E-02 & $2.59 \mathrm{E}-01$ & 4.71E-04 & $1.61 \mathrm{E}-02$ & $1.41 \mathrm{E}-03$ & $2.61 \mathrm{E}-03$ & 2.01E-02 & 7.27E-06 \\
\hline YG-3 & 2.27E-01 & $3.56 \mathrm{E}-03$ & $2.18 \mathrm{E}-02$ & $2.52 \mathrm{E}-01$ & 5.11E-04 & $1.75 \mathrm{E}-02$ & $5.63 \mathrm{E}-04$ & $1.38 \mathrm{E}-03$ & $1.94 \mathrm{E}-02$ & $7.89 \mathrm{E}-06$ \\
\hline YG-4 & 3.07E-01 & $7.56 \mathrm{E}-03$ & $4.28 \mathrm{E}-02$ & $3.57 \mathrm{E}-01$ & $6.91 \mathrm{E}-04$ & 2.37E-02 & $1.20 \mathrm{E}-03$ & $2.71 \mathrm{E}-03$ & $2.76 \mathrm{E}-02$ & $1.07 \mathrm{E}-05$ \\
\hline YG-5 & $1.91 \mathrm{E}-01$ & $1.33 \mathrm{E}-03$ & $1.75 \mathrm{E}-02$ & $2.10 \mathrm{E}-01$ & 4.31E-04 & 1.47E-02 & $2.11 \mathrm{E}-04$ & $1.11 \mathrm{E}-03$ & $1.61 \mathrm{E}-02$ & $6.65 \mathrm{E}-06$ \\
\hline YG-6 & $1.78 \mathrm{E}-01$ & 4.00E-03 & $6.08 \mathrm{E}-03$ & $1.88 \mathrm{E}-01$ & 4.01E-04 & $1.37 \mathrm{E}-02$ & $6.33 \mathrm{E}-04$ & $3.85 \mathrm{E}-04$ & $1.47 \mathrm{E}-02$ & $6.19 \mathrm{E}-06$ \\
\hline YG-7 & $1.87 \mathrm{E}-01$ & 8.89E-04 & $1.13 \mathrm{E}-02$ & $1.99 \mathrm{E}-01$ & 4.21E-04 & $1.44 \mathrm{E}-02$ & $1.41 \mathrm{E}-04$ & 7.17E-04 & $1.53 \mathrm{E}-02$ & $6.50 \mathrm{E}-06$ \\
\hline YG-8 & $1.33 \mathrm{E}-01$ & $1.33 \mathrm{E}-03$ & $1.98 \mathrm{E}-02$ & $1.54 \mathrm{E}-01$ & $3.01 \mathrm{E}-04$ & $1.03 \mathrm{E}-02$ & $2.11 \mathrm{E}-04$ & $1.25 \mathrm{E}-03$ & $1.18 \mathrm{E}-02$ & 4.64E-06 \\
\hline YG-9 & 8.44E-02 & 8.89E-04 & $1.84 \mathrm{E}-02$ & $1.04 \mathrm{E}-01$ & $1.90 \mathrm{E}-04$ & $6.52 \mathrm{E}-03$ & $1.41 \mathrm{E}-04$ & $1.17 \mathrm{E}-03$ & $7.82 \mathrm{E}-03$ & $2.94 \mathrm{E}-06$ \\
\hline YG-10 & $1.91 \mathrm{E}-01$ & $1.56 \mathrm{E}-01$ & $3.44 \mathrm{E}-01$ & $6.91 \mathrm{E}-01$ & 4.31E-04 & $1.47 \mathrm{E}-02$ & $2.46 \mathrm{E}-02$ & $2.18 \mathrm{E}-02$ & $6.11 \mathrm{E}-02$ & $6.65 \mathrm{E}-06$ \\
\hline YG-11 & $3.02 \mathrm{E}-01$ & $2.80 \mathrm{E}-02$ & $5.78 \mathrm{E}-02$ & $3.88 \mathrm{E}-01$ & $6.81 \mathrm{E}-04$ & $2.33 \mathrm{E}-02$ & $4.43 \mathrm{E}-03$ & $3.65 \mathrm{E}-03$ & $3.14 \mathrm{E}-02$ & $1.05 \mathrm{E}-05$ \\
\hline YG-12 & $1.20 \mathrm{E}-01$ & $1.78 \mathrm{E}-02$ & $7.21 \mathrm{E}-02$ & $2.10 \mathrm{E}-01$ & $2.71 \mathrm{E}-04$ & $9.26 \mathrm{E}-03$ & $2.81 \mathrm{E}-03$ & $4.56 \mathrm{E}-03$ & $1.66 \mathrm{E}-02$ & $4.18 \mathrm{E}-06$ \\
\hline YG-13 & $1.42 \mathrm{E}-01$ & 8.89E-04 & $1.18 \mathrm{E}-01$ & $2.61 \mathrm{E}-01$ & $3.21 \mathrm{E}-04$ & $1.10 \mathrm{E}-02$ & $1.41 \mathrm{E}-04$ & $7.46 \mathrm{E}-03$ & $1.86 \mathrm{E}-02$ & $4.95 \mathrm{E}-06$ \\
\hline YG-14 & $2.27 \mathrm{E}-01$ & $4.00 \mathrm{E}-03$ & $6.10 \mathrm{E}-02$ & $2.92 \mathrm{E}-01$ & $5.11 \mathrm{E}-04$ & $1.75 \mathrm{E}-02$ & $6.33 \mathrm{E}-04$ & $3.86 \mathrm{E}-03$ & $2.20 \mathrm{E}-02$ & $7.89 \mathrm{E}-06$ \\
\hline YG-15 & $2.53 \mathrm{E}-01$ & 4.44E-04 & 4.61E-02 & $3.00 \mathrm{E}-01$ & $5.71 \mathrm{E}-04$ & $1.96 \mathrm{E}-02$ & 7.03E-05 & $2.92 \mathrm{E}-03$ & $2.25 \mathrm{E}-02$ & $8.82 \mathrm{E}-06$ \\
\hline \multicolumn{11}{|c|}{ July-2017 } \\
\hline YG-5 & $5,29 \mathrm{E}-01$ & 2,36E-03 & $1,06 \mathrm{E}-02$ & $5,42 \mathrm{E}-01$ & 1,19E-03 & $4,08 \mathrm{E}-02$ & 3,74E-04 & $6,70 \mathrm{E}-04$ & 4,19E-02 & $1,84 \mathrm{E}-05$ \\
\hline YG-6 & $4,62 \mathrm{E}-01$ & $1,70 \mathrm{E}-03$ & $1,67 \mathrm{E}-02$ & $4,81 \mathrm{E}-01$ & 1,04E-03 & $3,57 \mathrm{E}-02$ & 2,69E-04 & $1,05 \mathrm{E}-03$ & $3,70 \mathrm{E}-02$ & $1,61 \mathrm{E}-05$ \\
\hline YG-7 & $6,53 \mathrm{E}-01$ & $1,79 \mathrm{E}-03$ & $8,17 \mathrm{E}-03$ & $6,63 \mathrm{E}-01$ & 1,47E-03 & $5,04 \mathrm{E}-02$ & $2,83 \mathrm{E}-04$ & $5,17 \mathrm{E}-04$ & $5,12 \mathrm{E}-02$ & $2,27 \mathrm{E}-05$ \\
\hline YG-8 & 4,44E-01 & $1,60 \mathrm{E}-03$ & $1,71 \mathrm{E}-02$ & $4,63 \mathrm{E}-01$ & 1,00E-03 & $3,43 \mathrm{E}-02$ & $2,52 \mathrm{E}-04$ & $1,08 \mathrm{E}-03$ & $3,56 \mathrm{E}-02$ & $1,55 \mathrm{E}-05$ \\
\hline YG-9 & $4,13 \mathrm{E}-01$ & $4,53 \mathrm{E}-04$ & $1,53 \mathrm{E}-02$ & 4,29E-01 & $9,32 \mathrm{E}-04$ & $3,19 \mathrm{E}-02$ & $7,17 \mathrm{E}-05$ & 9,70E-04 & $3,29 \mathrm{E}-02$ & $1,44 \mathrm{E}-05$ \\
\hline YG-10 & $5,73 \mathrm{E}-01$ & 7,38E-03 & $1,42 \mathrm{E}-01$ & $7,23 \mathrm{E}-01$ & 1,29E-03 & $4,42 \mathrm{E}-02$ & $1,17 \mathrm{E}-03$ & 9,01E-03 & $5,44 \mathrm{E}-02$ & $2,00 \mathrm{E}-05$ \\
\hline YG-16 & $4,58 \mathrm{E}-01$ & $1,68 \mathrm{E}-02$ & $1,31 \mathrm{E}-02$ & $4,88 \mathrm{E}-01$ & 1,03E-03 & $3,53 \mathrm{E}-02$ & $5,32 \mathrm{E}-04$ & $8,28 \mathrm{E}-04$ & $3,67 \mathrm{E}-02$ & $1,59 \mathrm{E}-05$ \\
\hline
\end{tabular}

Boldface are the values that exceed the limit values

fluorosis, calcification of ligaments, mottling of teeth and deformation of bones (WHO 2011; Narsimha and Sudarshan 2017; Narsimha and Rajitha 2018). In July-2017, $\mathrm{HQ}_{\text {ingestion }}$ of YG-5, YG-7 and YG-10 samples for As element was more than 1. The hazard indexes (HI) of water samples except for YG-9 sample was more than 1.0. (Table 9). Arsenic intake with drinking water may cause adverse health effects and potential non-carcinogenic concern. For adults, $\mathrm{HQ}_{\text {dermal }}$ (hazard quotient by dermal absorption) of $\mathrm{As}, \mathrm{NO}_{3}$ and $\mathrm{F}$ parameters was all below unity, indicated that these metals posed little hazards via dermal absorption.

For October-2019 samples, carcinogenic risk of As through oral intake for adults is between $1.29 \times 10^{-4}$ and $8.19 \times 10^{-5}$ (Table 9) and these risk values are an acceptable value to human health. Similar results $\left(3.99 \times 10^{-4}\right.$ and $6.30 \times 10^{-4}$ ) were obtained in July-2017 samples. It can be said that the use of these waters as drinking water will not pose a cancer risk. However, all of the dermal route cancer risk values are above acceptable values for adults in October-2019 and July-2017 sample groups (Table 9). This suggests that dermal exposure over the lifetime may increase the risk of cancer.

The intake of arsenic with drinking water has health effects. Short-term effects such as diarrhea, abdominal pain, muscle weakness, vomiting and flushing of the skin begin approximately $30 \mathrm{~min}$ after drinking water. An arsenic content above $1.2 \mathrm{mg} / \mathrm{l}$ is sufficient for these effects to begin for adults. But, these symptoms may be seen in child at levels as low as $0.2 \mathrm{mg} / \mathrm{l}$. (Wang and Mulligan 2006). Prolonged exposure to lower concentrations of arsenic may cause chronically adverse health effects (Nichols et al. 1998). Previous studies reported adverse health effects including cardiovascular disease, peripheral vascular disease, skin lesions, neurologic and neurobehavioral effects, diabetes, hypertension, portal fibrosis of the liver, lung fibrosis diseases and carcinogenic effects through high arsenic intake (IARC 1987; Chen and Lin 1994; Y1ldız et al. 2008; Wu et al. 2009). 
Table 9 Hazard index for each element and cancer risk of As for adults

\begin{tabular}{|c|c|c|c|c|c|c|c|c|c|c|}
\hline & \multicolumn{5}{|l|}{ Adult- $\mathrm{HQ}_{\text {oral }}$} & \multicolumn{5}{|c|}{ Adult- $\mathrm{HQ}_{\text {dermal }}$} \\
\hline & As & $\mathrm{F}$ & $\mathrm{NO}_{3}$ & HI & As-Can.R & As & $\mathrm{F}$ & $\mathrm{NO}_{3}$ & $\mathrm{HI}$ & As-Can.R \\
\hline \multicolumn{11}{|c|}{ October-2019 } \\
\hline YG-1 & $6.57 \mathrm{E}-01$ & $3.33 \mathrm{E}-02$ & $6.89 \mathrm{E}-02$ & 7.59E-01 & $2.96 \mathrm{E}-04$ & $1.03 \mathrm{E}-04$ & $7.48 \mathrm{E}-04$ & $3.09 \mathrm{E}-03$ & $3.94 \mathrm{E}-03$ & 1.39E-07 \\
\hline YG-2 & $4.48 \mathrm{E}-01$ & $9.52 \mathrm{E}-02$ & $8.84 \mathrm{E}-02$ & $6.31 \mathrm{E}-01$ & 2.01E-04 & 7.00E-05 & $2.14 \mathrm{E}-03$ & $3.97 \mathrm{E}-03$ & $6.17 \mathrm{E}-03$ & 9.47E-08 \\
\hline YG-3 & $4.86 \mathrm{E}-01$ & $3.81 \mathrm{E}-02$ & $4.66 \mathrm{E}-02$ & $5.70 \mathrm{E}-01$ & 2.19E-04 & $7.59 \mathrm{E}-05$ & $8.55 \mathrm{E}-04$ & 2.09E-03 & $3.02 \mathrm{E}-03$ & 1.03E-07 \\
\hline YG-4 & $6.57 \mathrm{E}-01$ & 8.10E-02 & $9.16 \mathrm{E}-02$ & $8.30 \mathrm{E}-01$ & $2.96 \mathrm{E}-04$ & $1.03 \mathrm{E}-04$ & $1.82 \mathrm{E}-03$ & 4.11E-03 & $6.03 \mathrm{E}-03$ & 1.39E-07 \\
\hline YG-5 & 4.10E-01 & $1.43 \mathrm{E}-02$ & $3.75 \mathrm{E}-02$ & $4.61 \mathrm{E}-01$ & $1.84 \mathrm{E}-04$ & $6.40 \mathrm{E}-05$ & $3.21 \mathrm{E}-04$ & $1.68 \mathrm{E}-03$ & 2.07E-03 & 8.67E-08 \\
\hline YG-6 & 3.81E-01 & 4.29E-02 & $1.30 \mathrm{E}-02$ & 4.37E-01 & $1.71 \mathrm{E}-04$ & $5.96 \mathrm{E}-05$ & $9.62 \mathrm{E}-04$ & $5.85 \mathrm{E}-04$ & $1.61 \mathrm{E}-03$ & 8.06E-08 \\
\hline YG-7 & $4.00 \mathrm{E}-01$ & $9.52 \mathrm{E}-03$ & $2.43 \mathrm{E}-02$ & 4.34E-01 & $1.80 \mathrm{E}-04$ & $6.25 \mathrm{E}-05$ & 2.14E-04 & $1.09 \mathrm{E}-03$ & $1.37 \mathrm{E}-03$ & 8.46E-08 \\
\hline YG-8 & $2.86 \mathrm{E}-01$ & $1.43 \mathrm{E}-02$ & 4.23E-02 & 3.42E-01 & $1.29 \mathrm{E}-04$ & 4.47E-05 & $3.21 \mathrm{E}-04$ & $1.90 \mathrm{E}-03$ & $2.26 \mathrm{E}-03$ & 6.05E-08 \\
\hline YG-9 & $1.81 \mathrm{E}-01$ & $9.52 \mathrm{E}-03$ & $3.95 \mathrm{E}-02$ & $2.30 \mathrm{E}-01$ & $8.14 \mathrm{E}-05$ & $2.83 \mathrm{E}-05$ & $2.14 \mathrm{E}-04$ & $1.77 \mathrm{E}-03$ & $2.01 \mathrm{E}-03$ & 3.83E-08 \\
\hline YG-10 & 4.10E-01 & $1.67 E+00$ & 7.38E-01 & $2.81 E+00$ & $1.84 \mathrm{E}-04$ & $6.40 \mathrm{E}-05$ & 3.74E-02 & 3.31E-02 & 7.06E-02 & 8.67E-08 \\
\hline YG-11 & $6.48 \mathrm{E}-01$ & $3.00 \mathrm{E}-01$ & $1.24 \mathrm{E}-01$ & $1.07 E+00$ & 2.91E-04 & $1.01 \mathrm{E}-04$ & $6.73 \mathrm{E}-03$ & $5.55 \mathrm{E}-03$ & $1.24 \mathrm{E}-02$ & 1.37E-07 \\
\hline YG-12 & $2.57 \mathrm{E}-01$ & $1.90 \mathrm{E}-01$ & $1.54 \mathrm{E}-01$ & $6.02 \mathrm{E}-01$ & $1.16 \mathrm{E}-04$ & 4.02E-05 & 4.27E-03 & $6.93 \mathrm{E}-03$ & $1.12 \mathrm{E}-02$ & $5.44 \mathrm{E}-08$ \\
\hline YG-13 & $3.05 \mathrm{E}-01$ & $9.52 \mathrm{E}-03$ & $2.53 \mathrm{E}-01$ & 5.67E-01 & $1.37 \mathrm{E}-04$ & 4.77E-05 & $2.14 \mathrm{E}-04$ & $1.13 \mathrm{E}-02$ & $1.16 \mathrm{E}-02$ & $6.45 \mathrm{E}-08$ \\
\hline YG-14 & $4.86 \mathrm{E}-01$ & 4.29E-02 & $1.31 \mathrm{E}-01$ & $6.59 \mathrm{E}-01$ & 2.19E-04 & 7.59E-05 & $9.62 \mathrm{E}-04$ & $5.87 \mathrm{E}-03$ & $6.90 \mathrm{E}-03$ & 1.03E-07 \\
\hline YG-15 & $5.43 \mathrm{E}-01$ & $4.76 \mathrm{E}-03$ & $9.88 \mathrm{E}-02$ & $6.46 \mathrm{E}-01$ & $2.44 \mathrm{E}-04$ & $8.49 \mathrm{E}-05$ & $1.07 \mathrm{E}-04$ & $4.43 \mathrm{E}-03$ & $4.62 \mathrm{E}-03$ & 1.15E-07 \\
\hline YG-16 & 8.81E-01 & $3.45 \mathrm{E}-02$ & $2.65 \mathrm{E}-02$ & $1.02 E+00$ & $4.25 \mathrm{E}-04$ & $1.23 \mathrm{E}-04$ & 7.96E-04 & $1.45 \mathrm{E}-03$ & $2.35 \mathrm{E}-03$ & 2.12E-07 \\
\hline \multicolumn{11}{|c|}{ July-2017 } \\
\hline YG-5 & $1.13 E+00$ & $2.53 \mathrm{E}-02$ & 2.27E-02 & $1.18 E+00$ & $5.10 \mathrm{E}-04$ & $1.77 \mathrm{E}-04$ & $5.68 \mathrm{E}-04$ & $1.02 \mathrm{E}-03$ & $1.76 \mathrm{E}-03$ & 2.40E-07 \\
\hline YG-6 & $9.90 \mathrm{E}-01$ & $1.82 \mathrm{E}-02$ & $3.57 \mathrm{E}-02$ & $1.04 E+00$ & $4.46 \mathrm{E}-04$ & $1.55 \mathrm{E}-04$ & 4.09E-04 & $1.60 \mathrm{E}-03$ & $2.17 \mathrm{E}-03$ & 2.10E-07 \\
\hline YG-7 & $1.40 E+00$ & $1.92 \mathrm{E}-02$ & $1.75 \mathrm{E}-02$ & $1.44 E+00$ & $6.30 \mathrm{E}-04$ & 2.19E-04 & 4.31E-04 & $7.85 \mathrm{E}-04$ & $1.43 \mathrm{E}-03$ & 2.96E-07 \\
\hline YG-8 & $9.52 \mathrm{E}-01$ & $1.71 \mathrm{E}-02$ & $3.66 \mathrm{E}-02$ & $1.01 E+00$ & $4.29 \mathrm{E}-04$ & $1.49 \mathrm{E}-04$ & $3.84 \mathrm{E}-04$ & $1.64 \mathrm{E}-03$ & $2.18 \mathrm{E}-03$ & 2.02E-07 \\
\hline YG-9 & 8.86E-01 & $4.86 \mathrm{E}-03$ & $3.29 \mathrm{E}-02$ & $9.23 \mathrm{E}-01$ & 3.99E-04 & $1.38 \mathrm{E}-04$ & $1.09 \mathrm{E}-04$ & $1.47 \mathrm{E}-03$ & $1.72 \mathrm{E}-03$ & 1.87E-07 \\
\hline YG-10 & $1.23 E+00$ & $7.90 \mathrm{E}-02$ & $3.05 \mathrm{E}-01$ & $1.61 E+00$ & $5.53 \mathrm{E}-04$ & $1.92 \mathrm{E}-04$ & $1.77 \mathrm{E}-03$ & $1.37 \mathrm{E}-02$ & $1.57 \mathrm{E}-02$ & $2.60 \mathrm{E}-07$ \\
\hline YG-16 & $9.81 \mathrm{E}-01$ & $3.60 \mathrm{E}-02$ & $2.80 \mathrm{E}-02$ & $1.04 E+00$ & $4.41 \mathrm{E}-04$ & $1.53 \mathrm{E}-04$ & $8.08 \mathrm{E}-04$ & $1.26 \mathrm{E}-03$ & $2.22 \mathrm{E}-03$ & 2.08E-07 \\
\hline
\end{tabular}

Boldface are the values that exceed the limit values

\section{Conclusion}

Groundwater is the primary source used for drinking water in the study area. Drinking water in the study area is mostly supplied from springs. The most important of these springs is the Suçıkan spring, which was used as drinking water in the ancient city of Pisidia Antiokheia. This spring water is still used for the drinking water need of Yalvaç district. In this study, groundwater quality assessment has been carried out to assess its suitability for drinking in a predominantly rural area. In addition, possible health risk assessment has been made in the use of water as drinking water.

The main factor controlling groundwater chemistry in the study area is rock-water interaction. The groundwater chemistry changes with the composition of sedimentary rocks in the basin, flow path and residence time. The dominant water type is $\mathrm{Ca}-\mathrm{Mg}-\mathrm{HCO}_{3}$ in the basin. Other water types in the basin are $\mathrm{Mg}-\mathrm{Ca}-\mathrm{HCO}_{3}$ and $\mathrm{Ca}-\mathrm{HCO}_{3}$. The
$\mathrm{Mg}$ increase in some samples is due to the rock-water interaction in relation to dolomitic limestones, sandstone, and conglomerate. The results of major ion chemistry of groundwater in the Yalvaç-Gelendost basin suggest that the silicate weathering and ion exchange are the main controlling hydrogeochemical processes in the variation of groundwater quality. The dolomite (SId) and calcite (SIc) saturation indices of groundwater demonstrate that carbonate minerals are the main components in the aquifer environment and carbonate dissolution-precipitation processes continue Query.

The chemical quality of the groundwaters in the study area has been evaluated for drinking water use. The analysis results of major ions, trace elements and nitrogen derivatives of groundwaters were compared with Turkey Regulation on Water Intended for Human Consumption (TS266 2005) and the (WHO 2017). The analysis results of major ions, nitrogen derivatives and trace elements $(\mathrm{As}, \mathrm{B}, \mathrm{Ba}, \mathrm{Cr}, \mathrm{Cu}, \mathrm{Mn}$, $\mathrm{Pb}, \mathrm{Zn}$ ) of groundwaters do not exceed permissible limits. 
But, $\mathrm{F}^{-}$concentration of one sample exceeded the limit $(1.5 \mathrm{mg} / \mathrm{l})$ value. The increase of $\mathrm{F}$ in this water sample may be related to the sandstones of the Göksöğüt formation. The content of the As ranged from 9.3-14.7 $\mu \mathrm{g} / \mathrm{l}$ in July-2017 and 1.9-6.9 $\mu \mathrm{g} / \mathrm{l}$ in October-2019. For drinking water, the limit value of As is $10 \mu \mathrm{g} / \mathrm{l}$ at WHO (2017) standards. Arsenic content of groundwater is related to water-rock interaction and agricultural activities. The nitrate content of groundwater samples varies between $0.73-41.3 \mathrm{mg} / \mathrm{l}$ in the study area. The nitrate contents of groundwater do not exceeded the tolerable limit value of WHO (2017) and TS266 (2005). But, groundwater in the Yalvaç-Gelendost basin is affected with anthropogenic factors.

In this study, health risk assessment has been made for the parameters of As, $\mathrm{F}$ and $\mathrm{NO}_{3}$, which may have a negative health effect by evaluating the groundwater samples in terms of drinking water quality. The results for non-carcinogenic human health risks suggested that children are not non-carcinogenic risks associated with consumption of arsenic, fluoride and nitrate contaminated water. But, carcinogenic risk of As through oral intake creates health risks for children.

Potential non-carcinogenic effect is likely to occur for three well water samples for adults according to results for non-carcinogenic human health risks. For adults, $\mathrm{HQ}_{\mathrm{dermal}}$ (hazard quotient by dermal absorption) of $\mathrm{As}, \mathrm{NO}_{3}$ and $\mathrm{F}$ parameters was all below unity, indicated that these metals posed little hazards via dermal absorption. However, all of the dermal route cancer risk values are above acceptable values for adults in October-2019 and July-2017 sample groups and indicated that the ingestion of water with dermal exposure over a long life time could increase the probability of cancer. Arsenic is the main toxic element for human health in the study area. The arsenic content increased in the July 2017 samples in the study area. The increase of arsenic in the aquifer environment is associated with the use of pesticides in the study area. Due to the seasonal decreasing of the As, the negative effect of arsenic intake on health also decreases.

Acknowledgement This study was supported by Süleyman Demirel University Research Fund with the project number FYL-2019-7043.

Authors' contribution (optional: please review the submission guidelines from the journal whether statements are mandatory).

Funding This work was supported by the Research Fund of the Süleyman Demirel University. Project number: FYL-2019-7043.

\section{Declarations}

Conflicts of interest The author declares that they have no conflict of interest.

Open Access This article is licensed under a Creative Commons Attribution 4.0 International License, which permits use, sharing, adaptation, distribution and reproduction in any medium or format, as long as you give appropriate credit to the original author(s) and the source, provide a link to the Creative Commons licence, and indicate if changes were made. The images or other third party material in this article are included in the article's Creative Commons licence, unless indicated otherwise in a credit line to the material. If material is not included in the article's Creative Commons licence and your intended use is not permitted by statutory regulation or exceeds the permitted use, you will need to obtain permission directly from the copyright holder. To view a copy of this licence, visit http://creativecommons. org/licenses/by/4.0/.

\section{References}

Adams S, Titus R, Pietersen K, Tredoux G, Harris C (2001) Hydrochemical characteristics of aquifers near Sutherland in the Western Karoo, South Africa. J Hydrol 241:91-103. https://doi.org/ 10.1016/S0022-1694(00)00370-X

Aghazadeh N, Mogaddam A (2011) Investigation of hydrochemical characteristics of groundwater in the harzandat aquifer, northwest of Iran. Environ Monit Assess 176:183-195. https://doi. org/10.1007/s10661-010-1575-4

Asare-Donkor NK, Adimado AA (2020) Groundwater quality assessment in the northern and upper east regions of ghana. Environ Earth Sci 79:205. https://doi.org/10.1007/s12665-020-08956-x

Azaza FH, Ketata M, Bouhlila R, Gueddari M, Riberio L (2011) Hydrogeochemical characteristics and assessment of drinking water quality in Zeuss-Koutine aquifer, southeastern Tunisia. Environ Monit Assess 174:283-298. https://doi.org/10.1007/ s10661-010-1457-9

Back W (1966) Hydrochemical Facies and ground-water flow patterns in northern part of Atlantic coastal plain. AAPG Bull 44(7):1244-1245

Chebboh M, Allia Z (2015) Geochemistry and hydrogeochemical process of groundwater in the souf valley of low septentrional sahara, algeria. Afr J Environ Sci Technol 9(3):261-273. https:// doi.org/10.5897/AJEST2014.1710

Chen CJ, Lin LJ (1994) Human carcinogenicity and atherogenicity induced by chronic exposure to inorganic arsenic. In: Nriagu JO (ed) Arsenic in the environment; Part II: human health and ecosystem effects. John Wiley \& Sons Inc, New York, pp 109-131

Datta PS, Tyagi SK (1996) Major ion chemistry of groundwater in delhi area: chemical weathering processes and groundwater flow regime. J Geol Soc India 47:179-188

Davraz A, Karagüzel R, Soyaslan II, Şener Ş, Seyman F, Şener S (2009) Hydrogeology of karst aquifer systems in SW Turkey and an assessment of water quality and contamination problems. Environ Geol 58:973-988. https://doi.org/10.1007/s00254-008-1577-5

Davraz A, Afşin M, Aksever F, Karataş Z, Hınıs MA (2016) The interference of a deep thermal system with a shallow aquifer and health risk assessment: the case of sandikli (afyonkarahisar). Environ Earth Sci 75:332. https://doi.org/10.1007/s12665-015-5144-6

Durov SA (1948) natural waters and graphic representation of their compositions. Dokl Akad Nauk SSSR 59:87-90

Elango L, Kannan R, (2007) Rock-water interaction and its control on chemical composition of groundwater. Section II, Paper 11, Developments in Environmental Science 5, Series Editor: S.V. Krupa; Concepts and Applications in Environmental Geochemistry, Edited by D. Sarkar, R. Datta, R. Hannigan, Elsevier publication, pp 229-247

Garcia MG, Hidalgo M, Blesa MA (2001) Geochemistry of groundwater in the alluvial plain of Tucum'an province,

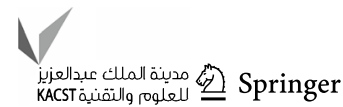


Argentina. Hydrogeol J 9:597-610. https://doi.org/10.1007/ s10040-001-0166-4

Gibbs RJ (1970) Mechanism controlling world water chemistry. Science 170:795-840

Guler C, Thyne GD, McCray JE, Turner AK (2002) Evaluation of graphical and multivariate statistical method for classification of water chemistry data. Hydrogeol J 10(4):455-474. https://doi.org/ 10.1007/s10040-002-0196-6

Han D, Liang X, Jin M, Currell MJ, Han Y, Song X (2009) Hydrogeochemical indicators of groundwater flow systems in the yangwu river alluvial fan, xinzhou basin, shanxi, China. Environ Manag 44:243-255. https://doi.org/10.1007/s00267-009-9301-0

Hounslow AW (1995) Water quality data analysis and interpretation. Lewis Publishers, Boca Raton

IARC (1987) Monographs on the evaluation of carcinogenic risks of chemicals to humans. Supplement F. overall evaluation of Carcinogenicity. International Agency for Research on Cancer. World Health Organization. Lyon, France, pp 29-57

IRIS (Integrated Risk Information System) (2005) US Environmental Protection Agency, Cincinnati, OH. Accessed at: (http://www. epa.gov/iris)

Jalali M, Ghanbari M, Jalali M (2019) Geochemical and environmental health threat evaluation of heavy metals in groundwater of Asad Abad, Hamedan. Iran Environ Earth Sci 78:699. https://doi.org/ 10.1007/s12665-019-8704-3

Jankowski J, Acworth RI (1997) Impact of debris-flow deposits on hydrogeochemical process and the development of dry land salinity in the Yass River catchment, New South Wales. Aust Hydrogeol J 5(4):71-88

Johnson CC (1979) Land application of waste-an accident waiting to happen. Groundwater 17(1):69-72

Katz BG, Coplen TB, Bullen TD, Davis JH (1998) Use of chemical and isotopic tracers to characterize the interaction between groundwater and surface water in Mantled Karst. Groundwater 35:1014-1028

Kavcar P, Sofuoglu A, Sofuoglu S (2009) a health risk assessment for exposure to trace metals via drinking water ingestion pathway. Int J Hyg Environ Health 212:216-227. https://doi.org/10.1016/j. ijheh.2008.05.002

Kuldip S, Hundal HS, Dhanwinder S (2011) Geochemistry and assessment of hydrogeochemical processes in groundwater in the southern part of Bathinda district of Punjab, northwest India. Environ Earth Sci 64:1823-1833. https://doi.org/10.1007/ s12665-011-0989-9

Kumar M, Ramanathan AL, Rao MS, Kumar B (2006) Identification and evaluation of hydrogeochemical processes in the groundwater environment of Delhi, India. Environ Geol 50:1025-1039. https:// doi.org/10.1007/s00254-006-0275-4

Kumar M, Kumari K, Kumar Singh U, Ramanathan AL (2009) Hydrogeochemical processes in the groundwater environment of Muktsar, Punjab: conventional graphical and multivariate statistical approach. Environ Geol 57:873-884. https://doi.org/10.1007/ s00254-008-1367-0

Kumar Singh A, Mondal GC, Singh TB, Singh S, Tewary BK, Sinha A (2012) Hydrogeochemical processes and quality assessment of groundwater in Dumka and Jamtara districts, Jharkhand, India. Environ Earth Sci 67:2175-2191. https://doi.org/10.1007/ s12665-012-1658-3

Lakshmanan E, Kannan R, Senthil Kumar M (2003) Major ion chemistry and identification of hydrogeochemical processes of ground water in a part of Kancheepuram district, Tamil Nadu. India Environ Geosci 10(4):157-166. https://doi.org/10.1306/eg100403011

Langmuir D (1997) Aqueous environmental geochemistry. Prentice Hall, Inc.

Li S, Zhang Q (2010) Risk assessment and seasonal variations of dissolved trace elements and heavy metals in the Upper Han River.
China J Hazard Mater 181(1-3):1051-1058. https://doi.org/10. 1016/j.jhazmat.2010.05.120

Lim HS, Lee JS, Chon HT, Sager M (2008) Heavy metal contamination and health risk assessment in the vicinity of the abandoned Songcheon Au-Ag mine in Korea. J Geochem Explor 96:223230. https://doi.org/10.3390/ijerph14121557

Liu F, Song X, Yang L, Zhang Y, Han D, Ma Y, Bu H (2015) Identifying the origin and geochemical evolution of groundwater using hydrochemistry and stable isotopes in the Subei Lake basin, Ordos energy base, Northwestern China. Hydrol Earth Syst Sci 19:551565. https://doi.org/10.5194/hess-19-551-2015

Lloyd JA, Heathcote JA (1985) Natural inorganic hydrochemistry in relation to groundwater: an introduction. Press, New York, Oxford Uni, p 296

Mahaqia A, Moheghy MA, Moheghi MM, Mehiqi M, Zandvakili Z (2020) Environmental hydrogeochemistry characteristics, controlling factors and groundwater quality assessment in herat city. West Afghan Water Resour 47(2):325-335. https://doi.org/10. 1134/S0097807820020104

Malakootian M, Mohammadi A, Faraji M (2020) Investigation of physicochemical parameters in drinking water resources and health risk assessment: a case study in NW Iran. Environmental Earth Sciences 79:195. https://doi.org/10.1007/s12665-020-08939-y

Mayback M (1987) Global chemical weathering of surficial rocks estimated from river-dissolved loads. Am J Sci 287:401-428

Means B (1989) Risk-assessment guidance for superfund. Volume 1. Human health evaluation manual. Part A. Interim report (Final). Environmental Protection Agency, Washington DC, USA. Office of Solid Waste. https://www.osti.gov/bibli o/70377 57. Accessed 4 Feb 2019

Narsimha A, Rajithac S (2018) Spatial distribution and seasonal variation in fluoride enrichment in groundwater and its associated human health risk assessment in Telangana State, South India. Hum Ecol Risk Assess 24(8):2119-2132. https://doi.org/10.1080/ 10807039.2018.1438176

Narsimha A, Sudarshan V (2017) Contamination of fluoride in groundwater and its effect on human health: a case study in hard rock aquifers of Siddipet, Telangana State, India. Appl Water Sci 7:2501-2512. https://doi.org/10.1007/s13201-016-0441-0

Nichols TA, Morris JS, Mason MM, Spate VL, Baskett CK, Cheng TP, Tharp CJ, Scott JA, Horsman TL, Colbert JW, Rawson AE, Karagas MR, Stannard V (1998) The study of human nails as an intake monitor for arsenic using neutron activation analysis. J Radioanal Nucl Chem 236(1-2):51-57. https://doi.org/10.1007/BF02386317

Parkhurst DL, Appelo CAJ (1999) User's guide to PHREEQC (version 2): a computer program for speciation, batch reaction, one dimensional transport, and inverse geochemical calculations. USGS Water-Resour Investig Rep 99(4259):312

Pazand K, Hezarkhani A, Ghanbari Y, Aghavali N (2012) Geochemical and quality assessment of groundwater of Marand Basin, East Azarbaijan Province, northwestern Iran. Environ Earth Sci 67:1131-1143. https://doi.org/10.1007/s12665-012-1557-7

Piper AM (1944) A graphic procedure in the geochemical interpretation of water analyses. Trans Amer Geophys Union 25:914-923

Ravikumar P, Somashekar RK, Prakash KL (2015) A comparative study on usage of Durov and Piper diagrams to interpret hydrochemical processes in groundwater from SRLIS river basin, Karnataka, India. Elixir Earth Sci 80:31073-31077

Şahinci A (1991) Geochemistry of natural waters. Reform Printing House, İzmir, p 546

Sajil Kumar PJ (2013) Interpretation of groundwater chemistry using piper and chadha's diagrams: a comparative study from perambalur taluk. Elixir Geosci 54:12208-12211

Sarvestani RA, Aghasi M (2019) Health risk assessment of heavy metals exposure (lead, cadmium, and copper) through drinking 
water consumption in Kerman city. Iran Environ Earth Sci 78:714. https://doi.org/10.1186/s12199-019-0812-x

Schoeller H (1967) Qualitative evaluation of groundwater resources. In: Methods and techniques of groundwater investigation and development. Water Research, Series-33. UNESCO, Paris, pp. 44-52

Schoeller H (1977)Geochemistry of groundwater. In: Groundwater studies-An International guide for research and practice. UNESCO, Paris, Chap 15: 1-18

Sener E, Soyaslan II (2006) Evaluation of karstic discharges in the east of Egirdir lake (Turkey) using satellite images. In: The III international scientific and practical conference (Use of the water resources and its integretional management in globalization processes), Bakü, pp. 70-72

Shakerkhatibi M, Mosaferi M, Pourakbar M, Ahmadnejad M, Safavi $\mathrm{N}$, Banitorab F (2019) Comprehensive investigation of groundwater quality in the north-west of Iran: physicochemical and heavy metal analysis. Groundw Sustain Dev 8:156-168. https://doi.org/ 10.1007/s12665-019-8655-8

Shankar S, Shanker U, Shikha S (2014) Arsenic contamination of groundwater: a review of sources, prevalence, health risks, and strategies for mitigation. Sci World J. https://doi.org/10.1155/ 2014/304524

Shukla S, Saxena A (2020) Groundwater quality and associated human health risk assessment in parts of Raebareli district, Uttar Pradesh India. Groundw Sustain Dev 10:100366. https://doi.org/10.1016/j. gsd.2020.100366

Singh AK, Mahato MK, Neogi B, Tewary BK, Sinha A (2012) Environmental geochemistry and quality assessment of mine water of Jharia coalfield, India. Environ Geol 65:49-65. https://doi.org/10. 1007/s10230-015-0382-0

Soyaslan I (2004) Hydrogeology Examination of Eğirdir Lake East and Groundwater Modeling. SDU Institute of Science and Technology, $\mathrm{PhD}$ thesis, Isparta (unpublished)

Subramani T, Rajmohan N, Elango L (2010) Groundwater geochemistry and identification of hydrogeochemical processes in a hard rock region, Southern India. Environ Monit Assess 162:123-137. https://doi.org/10.1007/s10661-009-0781-4

Tay CK (2012) Hydrochemistry of groundwater in the Savelugu-Nanton District, Northern Ghana. Environ Earth Sci 67:2077-2087. https://doi.org/10.1007/s12665-012-1647-6

TS266 (2005) Water intended for human consumption. Standards for drinking waters, Turkish Standards Institute, Ankara (in Turkish)

Umut M (2009) General Directorate of Mineral Research and Exploration, 1/100000 scale Geological Map of Turkey, Afyon-L26 Plot No: 119, Ankara (in Turkish)

USEPA (1986) Guidelines for Carcinogen Risk Assessment. U.S. Environmental Protection Agency, Washington DC. EPA/600/8-87/045.

USEPA (2001) Risk Assessment Guidance for Superfund, Volume 1: Human Health Evaluation Manual (Part E, Supplement Guidance for Dermal Risk Assessment). Office of Emergency and Remedial Response, Washington, DC
USEPA (2004) Risk Assessment Guidance for Superfund Volume I: Human Health Evaluation Manual (Part E, Supplemental Guidance for Dermal Risk Assessment) Final. EPA/540/R/99/005 OSWER 9285.7-02EP PB99-963312 July 2004, Office of Superfund Remediation and Technology Innovation U.S. Environmental Protection Agency Washington, DC, 2004.

USEPA (2013) Risk Assessment IRIS (Integrated Risk Information System). http://www.epa.gov/risk_assessment

Varol S, Davraz A (2016) Evaluation of potential human health risk and investigation of drinking water quality in isparta city center (Turkey). J Water Health 14(3):471-488. https://doi.org/10.2166/ wh.2015.187

Wang S, Mulligan C (2006) Occurrence of arsenic contamination in Canada: sources, behavior and distribution. Sci Total Environ 366:701-721. https://doi.org/10.1016/j.scitotenv.2005.09.005

WHO (2011) Guidelines for Drinking-Water Quality, 4th edn., World Health Organization, WHO Library Cataloguing-in-Publication Data, ISBN: 9789241548151

WHO (2017) Guidelines for Drinking-Water Quality. WHO Library Cataloguing-in-Publication Data, Fourth Edition Incorporating The First Addendum

Wu B, Zhao D, Jia H, Zhang Y, Zhang X, Cheng S (2009) Preliminary risk assessment of trace metal pollution in surface water from Yangtze River in Nanjing section, China. Bull Environ Contam Toxicol 82:405-409. https://doi.org/10.1007/s00128-008-9497-3

Yağmurlu F (1991) Stratigraphy and storage media of the YalvaçYarıkkaya Neogene Basin. Turkey Geol Bull 34:9-19 (in Turkish)

Yıldız A, Karaca M, Biçeroğlu S, Nalbantçılar MT, Coşkun U, Arık F, Aliyev F, Yiğiner Ö, Türkoğlu C (2008) Effect of chronic arsenic exposure from drinking waters on the QT interval and transmural dispersion of repolarization. J Int Med Res 36(3):471-478. https:// doi.org/10.1177/147323000803600311

Yu B, Wang Y, Zhou Q (2014) Human health risk assessment based on toxicity characteristic leaching procedure and simple bioaccessibility extraction test of toxic metals in urban street dust of Tianjin, China. PLoS ONE 9:924-959. https://doi.org/10.1371/ journal.pone.0092459

Zaidi FK, Nazzal Y, Jafri MK, Naeem M, Ahmed I (2015) Reverse ion exchange as a major process controlling the groundwater chemistry in an arid environment: a case study from northwestern Saudi Arabia. Environ Monit Assess 187:607. https://doi.org/10.1007/ s10661-015-4828-4

Zaidi FK, Salman A, Hag-Elsafi S, Alfaifi HJ (2019) Assessment of hydrological processes operating in a multi-layered sedimentary aquifer system in Saudi Arabia using integrated chemical and statistical approach. Environ Monit Assess 191:460. https://doi.org/ 10.1007/s10661-019-7597-7

Publisher's Note Springer Nature remains neutral with regard to jurisdictional claims in published maps and institutional affiliations. 